\title{
Coğrafi Tabanlı Sosyal Medya Kullanımı: Ankara'da En Çok Yer Bildirimi Yapılan Kahve Mekânları
}

\author{
Hüsna İpek BÜYÜKDEMiRCi*, Özge ERCOŞKUN \\ Gazi Üniversitesi, Mimarlık Fakültesi, Şehir ve Bölge Planlama Bölümü, 06570, Ankara, Türkiye. \\ *e-mail: ipek.bdemirci@gmail.com
}

Öz

Günümüzde teknoloji geliştikçe araştırma teknikleri de değişmektedir. Değişen teknoloji ile birlikte farkı araştırma teknikleri de ortaya çıkmaktadır. Bu çalışmada coğrafi sosyal ağlardan Foursquare-Swarm uygulamaları temel alınarak kent plancılara örnek olabilecek araştırma ve analiz sistemi ele alınmaktadır. Ankara kenti kahve mekânlarında Swarm kullanımına bağlı yer bildirimlerinde, rastgele-belirli sayıda seçilmiş kullanıcılar ankete tabi tutulmuştur. Çalışmada en çok yer bildirimi yapılan kahve mekânlarındaki kullanıcı profilleri, kullanıcı davranışları, mekânı seçme nedenleri, Foursquare-Swarm kullanımına yönelik sorular sorulmuştur. Foursquare-Swarm uygulamaları genellikle 20-24 yaşları arasındaki bekârlar, öğrenciler tarafından kullanılmaktadır. Katılımcıların iş yerlerinin ve evlerin konumu tercih ettikleri kahve mekânlarını etkilemektedir. Katılımcılar için AVM'ye, kent merkezine (Ulus, Kızılay, Tunalı), ana alışveriş caddesine yakınlık önemlidir. Kahve mekânları katılımcılar için rutin olarak gidilen bir yer olup mekânın iç tasarımı, açık alan kullanımı, otopark imkânı sunulması, toplu taşım kullanımına yakınlığı gibi etmenler tercihlerini etkilemektedir. Yer bildirimi sayısı insanların bir mekâna gitmeden önceki tercihinde etkili olmakla birlikte, mekânda sunulan ürün çeşitliliği, ürün fiyatları mekânın tercihinde önemli rol oynamaktadır. Tüm bu etmenlerle birlikte yer bildirimleri mekâna anlam katmaktadır.

Anahtar Kelimeler: Coğrafi sosyal ağlar, yer bildirimi, kent planlama, kentsel okuma, Ankara

\section{Use of Geo-Social Media: Top Check-ins Coffee Shops in Ankara}

\begin{abstract}
Today, as technology develops, research techniques also change. Along with the changing technology, different research techniques are emerging. In this study, the research and analysis system is discussed on FoursquareSwarm applications of geographical social networks, which can be used by urban planners. The randomlyselected users were surveyed in the reports of Swarm in top ten coffee shops in Ankara. User profiles, user behaviors, reasons for choosing the venue, questions about the use of Foursquare-Swarm were asked in the top coffee shops. Foursquare-Swarm applications are usually used by students, between age of 20-24. The work places and the location of the houses of the users influence the coffee shops they prefer. The proximity to the shopping mall, the city center (Ulus, KIzIlay, Tunalı) and the main shopping street are important for the users. Coffee shops are a routine place for the users and the factors such as the interior design of the shop, the use of outdoor space, the parking facilities and the proximity to public transportation affect their preferences. While the number of location notifications is important in user's preference before going to a venue, the variety of products offered in the place, the prices of products play an important role in the preference of the venue. With all these factors, venue comments add meaning to the place.
\end{abstract}

Key words: Geographical social networks, check-ins, urban planning, urban reading, Ankara

\section{Giriş}

Coğrafi sosyal ağlar aracılığı ile konum bilgileri, Global Position System (GPS) teknolojisi yardımıyla, kullanıcıların mekânda nasıl ve ne tarz davranış gösterdiği bilgisini sosyal medyaya yansıtır. Sosyal 
medya kullanıcılar tarafından olayları, aktiviteleri, mekânları takip etmede kolaylaştırıcı bir araçtır. Geleneksel yollarla (sosyal medya olmadan) farklı insanların olayları, aktiviteleri, mekânları takip etmesi sosyal medya kullanımına (örneğin Foursquare-Swarm uygulamalarında) göre çok daha zordur. Bu uygulamalarla sosyal medya kullanıcılarının konum bilgilerini takip edebilmek ve kullanıcıların da mekânlar hakkındaki bilgiye erişimi oldukça kolaydır.

Seyahat planlarını, mekân hareketliliklerini, nüfusun yoğunlaştığı en popüler noktaları FoursquareSwarm uygulamaları üzerinden görmek mümkündür. Kullanıcıların gün içerisinde kullandıkları mekânlar takip edilebilir, yer bildirimleri ile mekân ve kullanıcılar hakkında bilgi toplayabilir, veriler dâhilinde mekânın ihtiyaçları belirlenip alanın tasarımına girdi sağlanabilir.

Sosyal medya, tüm dünyada günlük hayatın bileşeni haline gelmiştir. Insanlar kolay internet bağlantıları ile sosyal medya kapsamında fotoğraf paylaşımıyla birlikte kentleri keşfetme ve yorumları alabilme durumuna gelmiştir. Sosyal medya ağları (Foursquare-Swarm gibi uygulamaları ile) coğrafikonum verilerini de barındıran iletişimimizin ve ilişkilerimizin zengin veri kaynaklarını oluşturmaktadır. Bu çalışma coğrafi tabanlı sosyal ağ kullanıcılarının (Foursquare-Swarm uygulamaları ile) mekânlardaki davranışlarını çözümlemeye çalışmakta olup Swarm uygulamasındaki geçmiş yer bildirimlerinin ve geçmişteki hareketliliğinin analizini ortaya koymaktadır. Çalışma, Ankara'daki en çok vakit geçirilen kahve mekânlarında yapılmıştır. En çok yer bildirimi yapılan 10 kahve mekânında (top 10) kullanıcı profilleri, kullanıcı davranışları, mekânı seçme nedenleri ve yer bildirimi kullanımına yönelik anket çalışması yapılmıştır. En çok yer bildirimi yapılan kahve mekânlarının kentin nerelerinde yoğunlaştığı ve diğer yer seçimi faktörleri sorgulanmıştır. Kahve mekânı işletmecileri ve kahve mekânlarındaki yer bildirimi yapan müşteriler anket çalışmasına tabi tutulup, anket analiz sonuçları araştırmada konu ile ilgili olarak toplanan veriler dâhilinde belli başlıklar altında analiz edilmiştir.

\section{Coğrafi Konum Tabanlı Sosyal Medya}

Sosyal medya, Web 2.0'ın kullanıcı hizmetine sunulmasıyla birlikte, tek yönlü bilgi paylaşımından, çift taraflı ve eş zamanlı bilgi paylaşımına ulaşıımasını sağlayan medya sistemidir. Ayrıca sosyal medya, kişilerin internet üzerinde birbirleriyle yaptığı diyaloglar ve paylaşımların bütünüdür. Sosyal ağlarla, insanların birbiriyle içerik ve bilgi paylaşmasını sağlayan internet siteleri ve uygulamalar sayesinde herkes aradığı, ilgilendiği içeriklere ulaşabilir (URL-1).

Sanayi toplumundan bilgi toplumuna geçişle birlikte iletişim alanındaki gelişmelerle, bilginin üretimi, depolanması ve paylaşılması zamandan ve mekândan bağımsız hale gelmiştir. Bilginin üretimi ve paylaşılmasıyla ilgili kaynaklar çeşitlenmiş bilgisayar ve mobil cihaz (akıllı telefon, tablet vs.) teknolojisindeki gelişmelerle mekâna bağımlııktan ve rutinden çıkılmıştır. Illetişim sürecinin yapısal dönüşüme uğraması sonucu interaktif, çok boyutlu, karşılıklı bir etkileşim süreci başlamıştır. Sosyal medya insanlar için haberleşme ve iletişim aracı olmanın ötesine geçerek sosyalleşme ve kendini ifade edebilme platformuna dönüşmüştür (Eren ve Aydın, 2014).

Sosyal medya, 2000'li yıllarla birlikte hayatımıza girmiş olup gelişmekte olan ve gelişmiş ülkelerdeki nüfusların hemen hepsi tarafından çok kolay bir şekilde kabullenilmiştir. Bu sosyal ağa ulaşmak oldukça kolaydır ve bu ortama girmek için gereken cihazlar da bir o kadar çeşitlidir. Yaşları fark etmeksizin her birey, gündemi, sosyal ağları ve herhangi teknolojik bir cihazın takibini kolaylıkla internet üzerinden yapabilmektedir. Insanlar sosyal medya üzerinden örgütlenebilmekte, bilgi aktarımı yapabilmekte ve haberleşebilmektedir. Bu da sosyal medyayı sadece bir eğlence mekânı olmaktan çıkarmakta ve önemini gözler önüne sermektedir (Arslan, 2014).

Sosyal medyanın önemi ve sosyal medyanın kullanımı günden güne artmaktadır. Mobil cihazlar ile her zaman her yerde bağlantı kurma imkânı sunulmaktadır. Sosyal medya kullanıcıları çeşitli sanal ürünleri görme imkânına sahiptir. Sosyal medya aracılığı ile birçok mekân ürünleri hakkında bilgi sunumu yapmakta olup sosyal ağlar arasındaki rekabet mekânların motivasyonu artırmaktadır.

Foursquare mobil cihazlar üzerindeki GPS (Global Position System-uydudan koordinat belirleme) teknolojisinden faydalanarak, cihaz kullanıcılarının bulundukları ortamda gitmek istedikleri mekânları 
görebilme amacıyla tasarlanmıştır. Foursquare ile Swarm kullanımının farkı; yer bildirimi yapmak isteyen kullanııların Swarm'ı, mekân aramak isteyen kullanıcılarında Foursquare'ı kullanmasıdır. Foursquare uygulamasından mekânı inceleyen kişi Swarm uygulamasına yönlendirilme ile yer bildirimini de yapabilir. Akıllı telefon uygulamalarından oldukça sık kullanılan Foursquare-Swarm uygulamaları ile bulunulan konum kullanılarak tüm sosyal ağlar üzerinden konum paylaşımı yapılabilir. Yer bildirimi yapılarak sadece bulunulan konum değil aynı zamanda bulunulan yerin hassas koordinatları zamana göre kaydetmiş olunur. Bu detaylar otomatik olarak yer ve zamana göre belirlenir.

Kullanııı; Foursquare ile mekânları şehir veya semte göre sıralayabilir, listedeki kalabalık mekânları inceleyerek mekân seçme konusunda daha kolay karar verip tercih yapabilir, ziyaretçilerin yazdığı tavsiyeleri eklenme tarihine göre sıralayarak okuyabilir, eklenen fotoğraflara göz atarak mekânlara gitmeden önce hakkında bilgi alabilir ve popüler mekânları kişisel listeye kaydederek daha sonra ziyaret edilebilir. Foursquare arkadaşlarla gidilebilecek en iyi mekânları bulmaya yardım edip, bulunan bölgedeki en iyi yemekleri, gece hayatını, eğlenceyi keşfetmeye olanak sağlar.

Kullanıııar, Swarm uygulaması ile kullanııılar arkadaşları ile iletişim kurarak, buluşma planları yapabilirler. Kullanıcı hangi arkadaşının yakında bulunduğunu görebilir ve yakında bulunan arkadaşlarını takip edebilir. GPS özelliğini kullanarak yer bildirimi yapıldığında mekânda bulunan insanları görebilir ve onlarla iletişime geçilebilir. Mekânı kaydederek de daha sonra gelmek istenilen yerleri kolaylıkla görebilir (http://foursquareturkiye.com).

13 Eylül 2016'da Foursquare ekibinin paylaştığı habere göre toplamda 10 milyar yer bildirimi sayısına ulaşılmıştır. Bu yer bildirimlerin 4'te 1'ini kapsayan 2,5 milyarının Türkiye'ye ait olması da önemli bir başka haberdir. 2,5 milyar yer bildirimi sayısıyla Türkiye, 2016 yılı 3. çeyreğinin sonlarında en çok yer bildirimi yapılan ülke konumuna gelmiştir. Türkiye'de ise Ankara ili İstanbul ilinden sonra yer bildirimi sayısı bakımından 2. Sırada yer almaktadır (URL-2). Şekil 1 ve Şekil 2'de beyaz renkteki alanlar yer bildirimi yapılan bölgeleri göstermektedir.

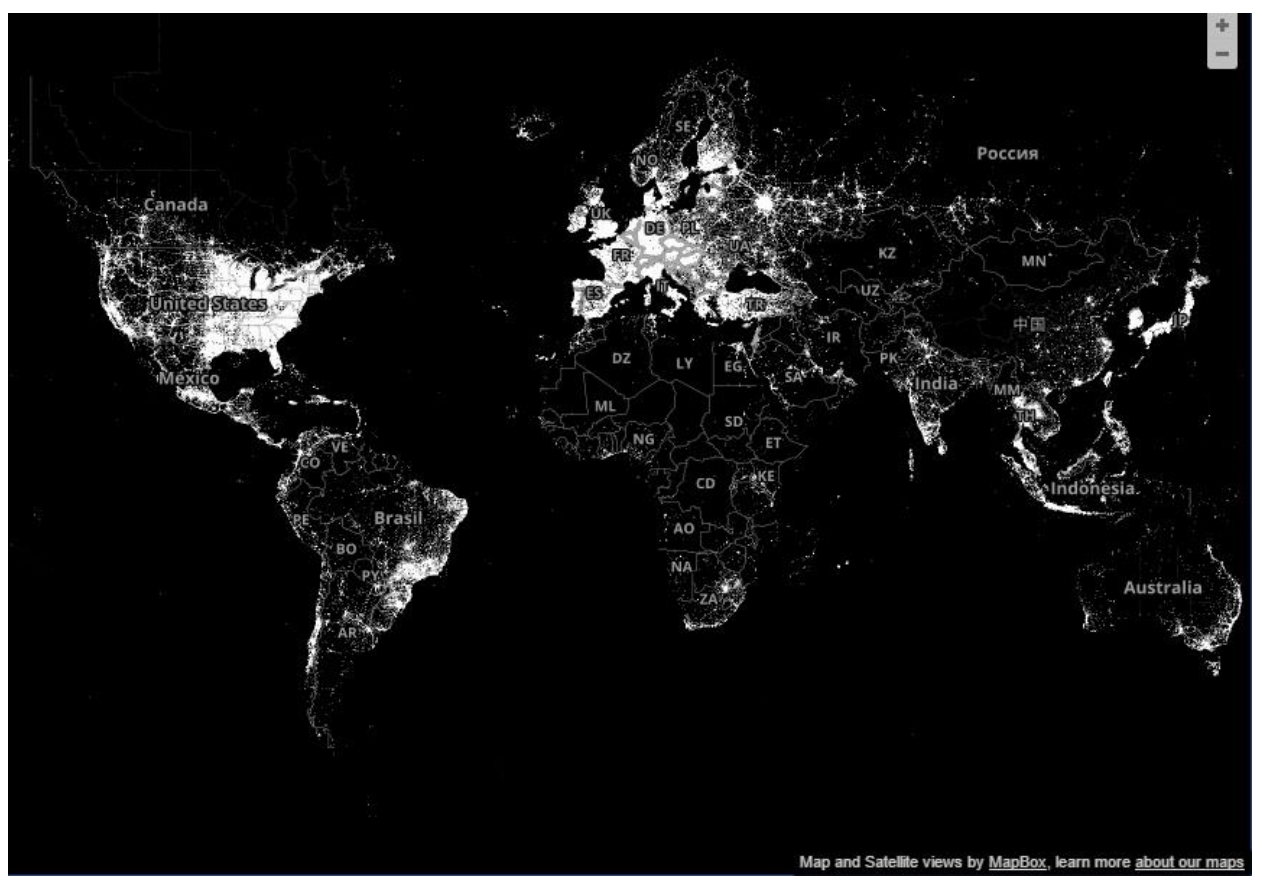

Şekil 1. Dünya'daki Foursquare uygulaması üzerinden yapılan son 500000000 yer bildirimi (URL-3). 


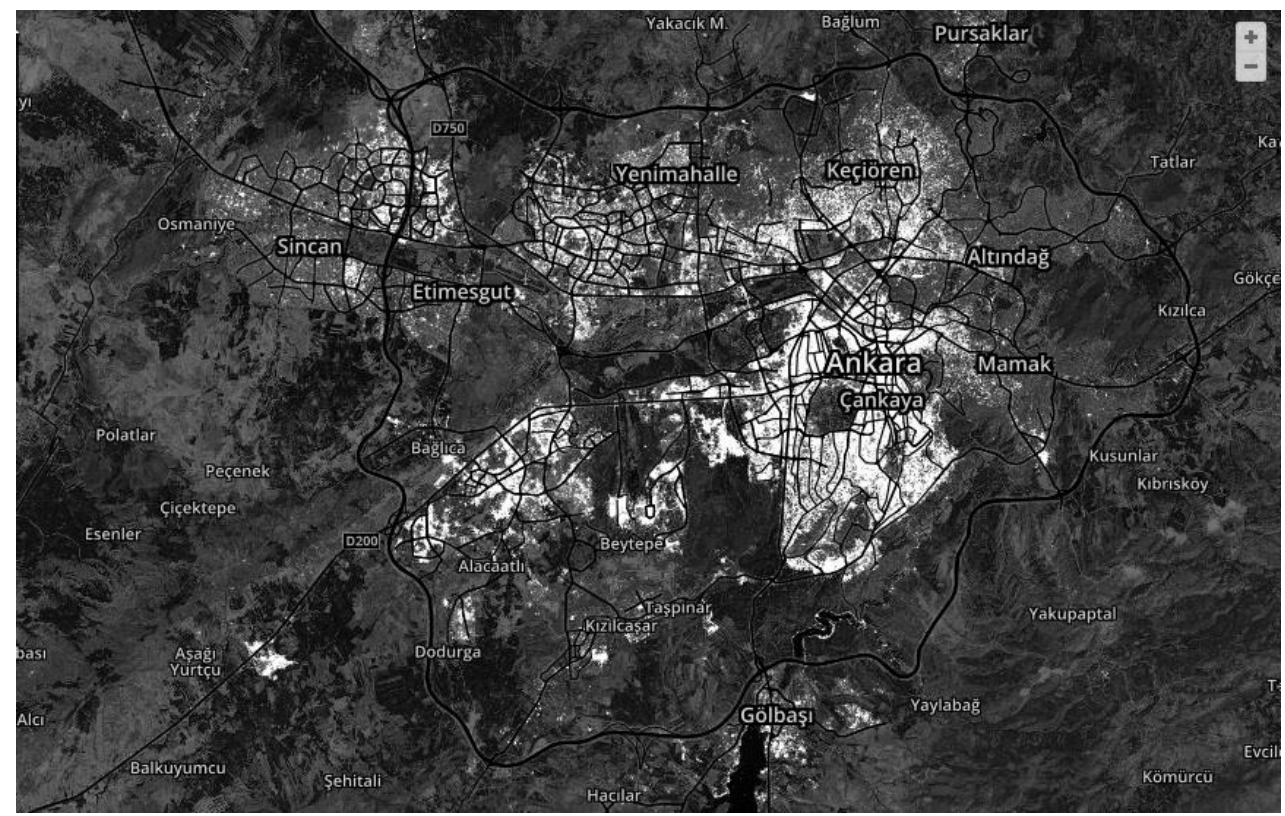

Şekil 2. Ankara'daki Foursquare uygulaması üzerinden yapılan son 500000000 yer bildirimi (URL-3).

\section{Coğrafi Konum Tabanlı Sosyal Medya Kullanımı}

Coğrafi konum tabanlı sosyal medya, kentliler ve kentteki mekânlar arasındaki iletişimi sanal mekân üzerinden sunması açısından önemli bir kaynaktır. Coğrafi konum tabanlı sosyal medya kullanımı ile öngörülen sistemde hangi mekânların öne çıktığı ve bu mekânların da ne ifade ettiği ortaya koyulmaktadır. Örneğin, özel bir kahve dükkânı arayan bir kişi kahve dükkânının web sitesine girerek veya doğrudan Foursquare uygulaması ile mekânın konum verisi, mekânın çalışma saatleri, mekân hakkındaki yorumlar ve beğeniler gibi temel bilgileri alabilirler. Şekil 3'de örnek olarak Kahveci Hacıbaba mekânının Foursquare uygulamasından elde edilebilecek temel bilgileri görülmektedir. 


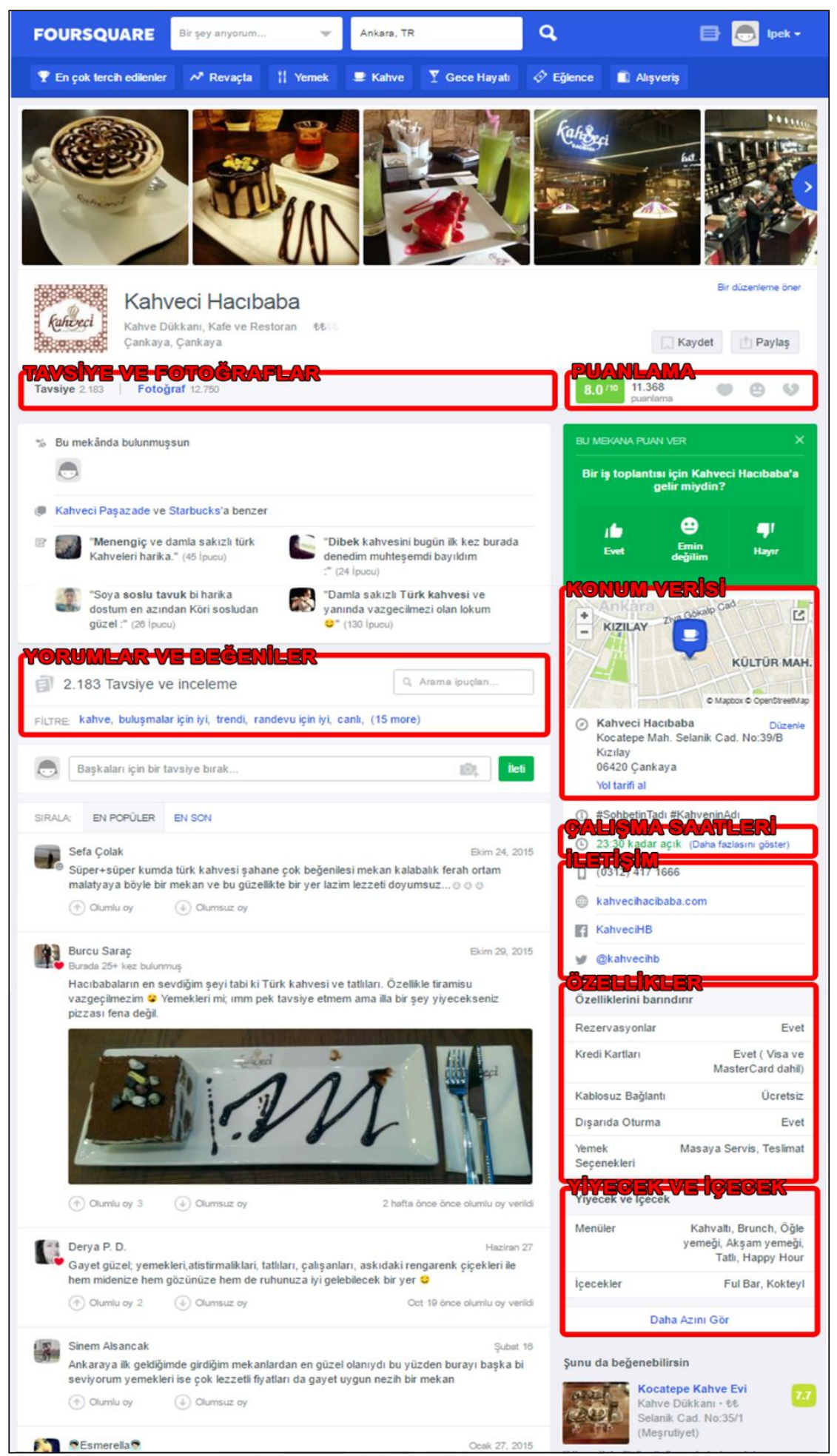

Şekil 3. Foursquare uygulaması ile elde edilebilecek temel veriler

\subsection{Coğrafi Konum Tabanlı Sosyal Medya Kullanımının Kentsel Okumaya ve Analizlere Girdisi}

Sosyal medya kentlerin yapılarını, dinamiklerini ve kimliklerini de ortaya koymaktadır. Sosyal medyayı milyonlarca insan kullanmaktadır ve günlük düzenli olarak milyonlarca veri paylaşılmaktadır. Paylaşılan verilerin pek çoğu GPS verisi olan konum verileri şeklindedir. Konum verileri insanların davranışlarının zaman içerisindeki değişikliğini sunmaktadır. Sosyal medya verisi olan konum verileri yeni bir araç olarak kent plancılarına, politika analistlerine, sosyal bilimcilere ve bilgisayar uzmanlarına insanların kentleri nasıl kullandıklarını ucuz, kolay ve ölçülebilir şekilde keşfetme olanağı sunar. Özellikle de kent plancıları için belediye sınırları içerisindeki demografik ve coğrafi kaynakları 
kullanmada, ekonomik kalkınmada, sosyal dokuyu anlamada, planlamada kenti analiz etme araçlarından biridir (Tasse ve Hong, 2014).

Sosyal medya, yalnızca kullanıcıların ne yaptığını nerede olduğunu söylemez, aynı zamanda konum verileri aracılı̆̆ıla mekânların hızlı ve ucuz yollarla en iyi yeri bulmaya yarar. Kentsel dinamikleri anlamada, yapılacak çalışmalarda (örneğin mekânların ulaşım bağlantıları, demografik özellikleri vb. analizler) geleneksel yollarla yapılırsa pahalı olmakta ve uzun süre almaktadır (Baraniuk, 2013). Ancak, sosyal medyanın kullanılmasının artmasıyla birlikte konum verilerinin işlenmesi bu analizlerin yapılmasında kolaylık sağlamaktadır. Bu sayede kentsel okuma kolaylaşmaktadır. Sosyal medya aracılığı ile yapılan konum verileri kullanılarak yapılan projelerde, kentsel tasarımlarda boşlukların nasıl tasarlanacağını, neler kullanılması gerektiği hakkında bilgi vermektedir (Tasse ve Hong, 2014).

Geleneksel yolların uygulandığı yöntemler kentleri ve kentlerde yaşayan insanları anlamada yavaş, pahalı ve ölçülemez durumdadır. Sosyal medyanın getirdiği konum verileri aracılığıyla plancıların, politikacıların, araştırmacıların ve iş adamlarının kullanabileceği zamansal veriler sunulmaktadır (Tasse ve Hong, 2014). Örneğin, Amerika'da son zamanlar da sıkça rastlanan sosyal medya üzerinden seçim kampanyaları adaylara pek çok imkân sunmuştur. Seçmenlerin bulundukları yerlerde yaptıkları yer bildirimleri üzerinden adaylara sosyal medya ile destek sağlanmaktadır. Aynı zamanda kitlelerin şehirlerde dağılımını "\#" işareti ile yazılan haberler aracılığıyla mekânlarda kaç kişinin bilgi sunmakta olduğunu takip etmeye yaramaktadır. Tüm bunların sonucunda seçim öncesi seçmenlerin nerede bulunduklarını ve kaç kişinin hangi mekânda bulunduğunun yanıtını coğrafi tabanlı sosyal medya üzerinden yapılan tahminlerle mümkün olmaktadır. Politikacılara coğrafi tabanlı sosyal medya daha birçok alanda yardımcı olmaktadır. Diğer bir örnek ise işadamlarının işletmelerinde yeni bir şube açacakları zaman coğrafi sosyal ağları kullanarak hitap ettiği kullanıcı kitlesi ve tercih edilen mekânların türleri gibi pek çok sınıflandırılmış bilgiye ulaşıp en doğru yerde en doğru maliyette en doğru yatırımı yapmasına olanak sağlar. Hatta söz konusu işadamı işletmesinin bir şubesini hiç bilmediği bir şehirde bile bu bilgiler ışığında gerçekleştirebilir. Özetle kent içerisinde yaşayan insanların bulundukları yer temel alınarak onların davranışları, yorumları, düşünceleri, seyahatleri ve bunların zaman içerisindeki mekânsal değişikliği gibi pek çok konuda araştırma yapmak isteyenlere kentsel alanda bilgi sunar.

\subsection{Coğrafi Konum Tabanlı Sosyal Medya Kullanımının Kent Planlamasına Girdisi}

Sosyal medya da konum verilerinin işlenmesiyle birlikte, kent plancılarına daha ölçülebilir ve hassas bilgiler sunulmaktadır. Bu bilgiler kent planlamayı geliştirmede ve kentsel kalitenin arttırılmasına imkân sunmaktadır. Sosyal medya konum verileri sayesinde insanların farklı noktalardaki, farklı yerlerdeki, farklı insanlarla etkileşimini sağlamakta ve yeni bir tanımlama yöntemi ortaya koymaktadır (Tasse ve Hong, 2014).

Konum verileri aynı zamanda sosyal davranış kalıpları gibi kullanıcı bilgilerini sunmaya yarar. Sosyal medya üzerinden konum verileri yayılmaktadır ve farklı alanlardaki konum verilerinin yayılımı takip etmeyi kolaylaştırmaktadır. Foursquare uygulaması tanıtımları, mekânla ilgili bilgilerin ve kişilerin mekândaki bilgilerinin yayılımının en kolay yoludur. Sosyal ağlar aracılığı ile Türkiye, İspanya, Brezilya gibi ülkelerdeki milyonlarca kişi mekân hareketliliğini kullanmada Foursquare-Swarm uygulamalarını kullanmaktadır. Bu veriler konum bilgilerine girdi oluşturmaktadır.

Bir bölgede planlama çalışması yapılacağı zaman o bölgeyle ilgili planın en önemli unsuru analiz aşamasıdır. Kent planlamaya altlık sağlayan analizler genellikle çeşitli haritalar üzerinden yapılmaktadır. Coğrafi tabanlı sosyal medya verileri kent planlama analizlerinde plancılara çeşitli boyutlarda girdi sağlamaktadır. Bunlar:

1- Arazi kullanımına ve fiziki mekânın tasarlanmasına veri sağlaması

2- Erişebilirlik, hareketliliğe girdi sağlaması

3- Yer Bildirimlerinin sosyo-ekonomik boyutunun analizinin yapılabilmesi 
şeklinde sınıflandırılabilir (Ercoşkun, 2015). Kent planlamaya girdi sağlayan bu boyutlar daha detaylı olarak aşağıda yer almaktadır.

Coğrafi sosyal ağlar, en genel anlamda kent plancılarına mekânı tanımalarında, kentlilerin sosyoekonomik yapısını çıkarımda bulunmada ve kent içerisindeki hareketliliği ulaşılabilirliği konusunda en güncel verilere masrafsız ulaşarak alternatif bir analiz türü olarak kullanılabilir. Bu konuda şöyle bir örnek verilebilir; geleneksel planlama analizlerinde açık alanlar içerisindeki ticaret alanlarının kişi yoğunluğunu ve merkezi iş alanlarının yoğunluğunu tespit etmekte rakamsal verilere ulaşmak zorlu bir süreçtir. Coğrafi tabanlı sosyal medya verilerinin planlama disiplini içerisinde analizi ele alındığında, ticaret alanlarında ve merkezi iş alanlarında kişi yoğunluğuna ulaşılabildiği gibi her bir ticari işletmede kaç kişinin günün hangi zamanında bulunduğunu, zaman içerisinde kişi sayısına ve kişilerin yaptığı görüş ve yorumlara ulaşılabilip haritalandırması geleneksel yöntemlere göre oldukça kolaydır. Coğrafi tabanlı sosyal medyanın geleneksel analiz yöntemlerine göre ayrıca ticari mekânların istenilen tarihsel süreçteki fiziksel mekândaki kaymaları, ticari mekânların ve merkezi iş alanlarının gelişim yönü, potansiyel ticaret alanlarının saptanması, söz konusu alanlara kişilerin ulaşım ve erişim olanaklarının sağlanması, kişi başına düşen ticari alanın ortalama hesabının yapılması ile planda öngörülecek ticari alanın boyutunun tasarlanmasında önemli bir rol oynar.

Kent plancıları kentin mekânları ve açık alan kullanımlarında odak noktalarını tespit etmekte yer bildirimlerini kullanabilirler. Belirli bir seviyenin üzerinde yer bildirimi yapılan mekânlar ve açık alan kullanımları kentte buluşma noktalarını oluşturmaktadır. Örneğin, Ankara'da bulunan açık ve yeşil alan kullanımlarından biri olan Seğmenler Parkı Foursquare ve Swarm uygulamalarında kentlilerin en çok tercih ettiği ve en çok kullandığı parktır.

Mekânlarda yapılan yer bildirimleri sonucu Swarm uygulaması jeton (coin) vermektedir. Bu çalışmaya yönelik Şekil 4 ve Şekil 5'de Swarm mobil uygulamasından elde edilen görüntüler bulunmaktadır. Kent plancılarının yaptıkları planların hayata geçmesiyle yeni gelişme alanlarında yapılan yer bildirimleri, gelişme alanlarının insanlara özellikle sosyal medyanın sunduğu "rozet-başarı puanı-keşif jetonu (coin)" gibi ödülleri vermesiyle mekânların popülerliğini arttırmakta, yeni oluşturulan gelişme alanlarının kuluçka evrelerini oldukça kısa sürede atlatmalarına olanak sağlamaktadır. Ayrıca dünya çapında coğrafi konum tabanlı sosyal medya kullanıcılarının arasında Türkiye'nin birinci sırada yer alması analizlerin güvenilirliğini artırmaktadır.

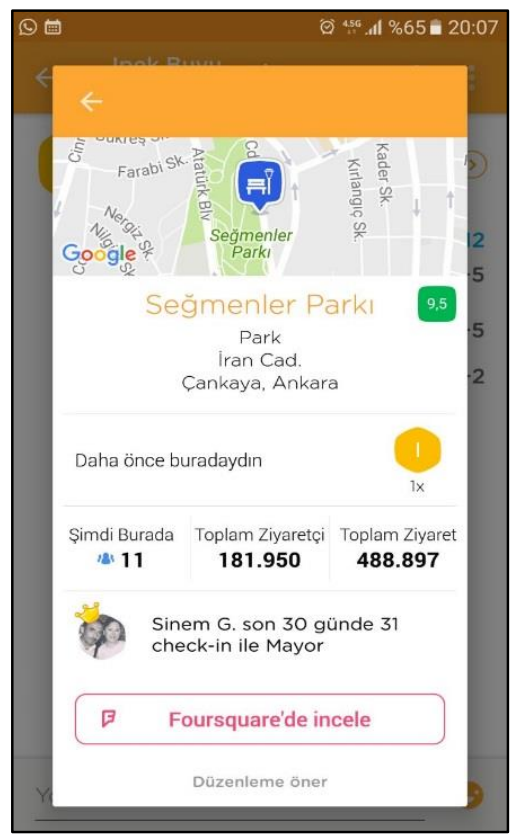

Şekil 4. Seğmenler Parkı toplam ziyaretçi, ziyaret sayıları (Swarm mobil uygulaması-Aralık 2016).

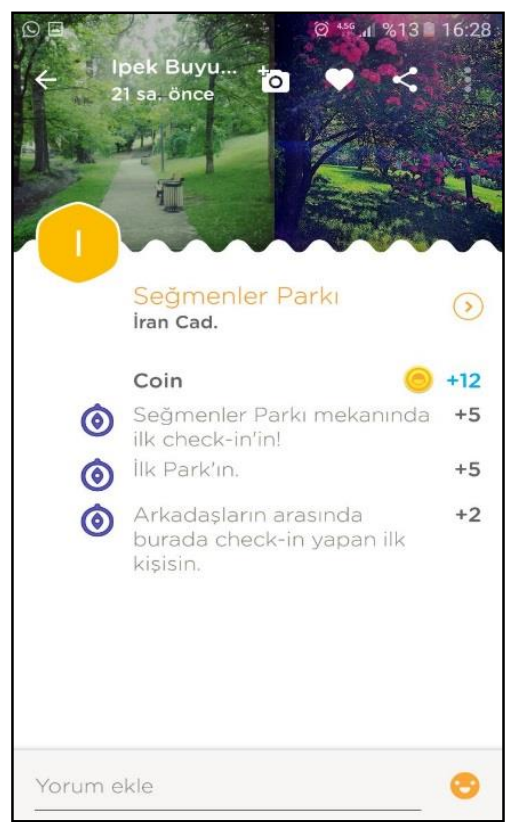

Şekil 5. Seğmenler Parkı yer-bildirimden gelen toplam jetonlar (Kaynakça: Swarm mobil uygulaması-Aralık 2016). 


\subsubsection{Arazi kullanımına ve fiziksel mekânın tasarlanmasına veri sağlaması}

Arazi kullanımının ve fiziksel mekânın haritalandırımasında ve oluşturulmasında daha önceden bahsedildiği gibi geleneksel yöntem ve modern yöntem kullanılabilir. Geleneksel yöntemle arazi kullanımının oluşturulmasında emek yoğun bir çalışma söz konusudur. Bu tarz analizler hazırlanırken hâlihazır haritalar kişiler tarafından sahada gezilerek tek tek işlenip oluşturulur. Bu analiz gerçekleştirilirken oldukça fazla zaman, para ve işgücü harcanır. Modern yöntemle arazi kullanımının oluşturulmasında kullanılan coğrafi tabanlı sosyal medyanın konum verilerinden yararlanarak işgücü, para ve zaman kaybı önlenebilir. Modern yöntemin geleneksel yönteme nazaran her zaman güncel olması önemli bir artıdır. Fiziksel mekânın içerisindeki her bir mekânın coğrafi tabanlı sosyal medya üzerinden analizi yapılırken üç temel unsur dikkate alınır. Bunlar; mekân türü analizi, mekânları gruplama, fiziki mekânın tasarlanmasındaki mekân-insan ilişkisidir.

\subsubsection{Mekân türü analizi:}

Mekân türü analizinde, sosyal medya içerisindeki ana başlık olarak verilen mekânlar;

Sanat-eğlence, sinema-tiyatro, müze, müzik mekanları, sanat gösterim mekanları, kamusal sanat mekanları, stadyumlar, tema parkları, kolej-üniversiteler, aktivite alanları, yemek yerleri, gece hayatı noktaları, rekreasyon ve açık hava mekanları, spor alanları, jimnastik salonları, plajlar, kayak yerleri, belediyeler, diğer aktivite alanları, açık alanlar, devlet binaları, sağlık merkezleri, ofisler, okullar, dini merkezler, konut alanları, alışveriş-servis alanları, bankalar, çocuk bakım alanları, giyim mağazaları, içkili restoranlar, mobilya ve ev eşyası dükkanları, havalimanı, terminaller, limanlar, tren istasyonları, oteller şeklindedir ve arazi kullanımı içerisinde yer alabilecek her türlü bilgi bulunmaktadır (URL-5).

Coğrafi tabanlı sosyal medya, mekânın türü ve kullanımını ortaya koymaktadır. Örneğin, Ankara'da kent merkezinde bulunan Kızılay AVM'nin kent içerisinde nerede konumlandığını, ana caddeye göre yakınlığını veya uzaklı̆̆ını, çevresindeki diğer kullanımlara (konut alanları, merkezi iş alanı, parklar, spor alanları, iş merkezleri vb.) göre konumunu göstermektedir.

\subsubsection{Mekânları gruplama:}

Mekânda gruplama yapılması Foursquare uygulamasının sunduğu frekanslara göre yapılır (Şekil 6). Foursquare'nin "En çok tercih edilenler" kısmında kullanıcıların memnuniyetine göre mekânın değerlendirme notu alması frekanslardan biridir. Örneğin, Seğmenler parkı 7038 puana dayanarak 10 puan üzerinden 9,5 puana layık görülmüştür (Şekil 7).

Bir başka frekans ise Foursquare'nin "En yakın" kısmında konum olarak kullanıcıya en yakın ve erişilebilir mekânları sunmasıdır. Yine bir diğer frekans ise Foursquare uygulamasının "Revaçta" kısmında mekânları gruplamasıdır. "Revaçta" gruplamasının, "En çok tercih edilenler" kısmına benzerliği yine kullanıc memnuniyetine dayanmasıdır, farkı ise "Revaçta" gruplamasının belirli bir zaman aralığında mekânlara artan ilginin olmasıdır. 


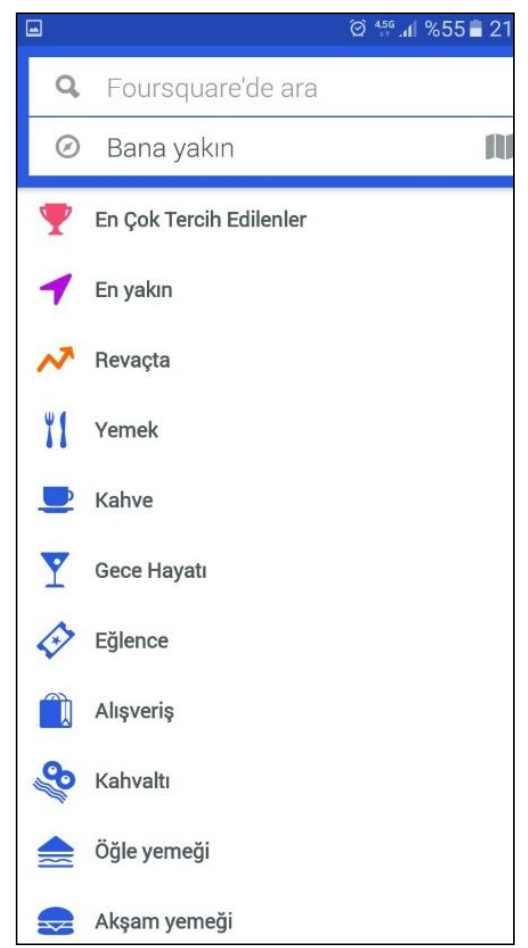

Şekil 6. Foursquare uygulamasında frekansa göre mekân gruplaması (Foursquare mobil uygulamasıAralık 2016).

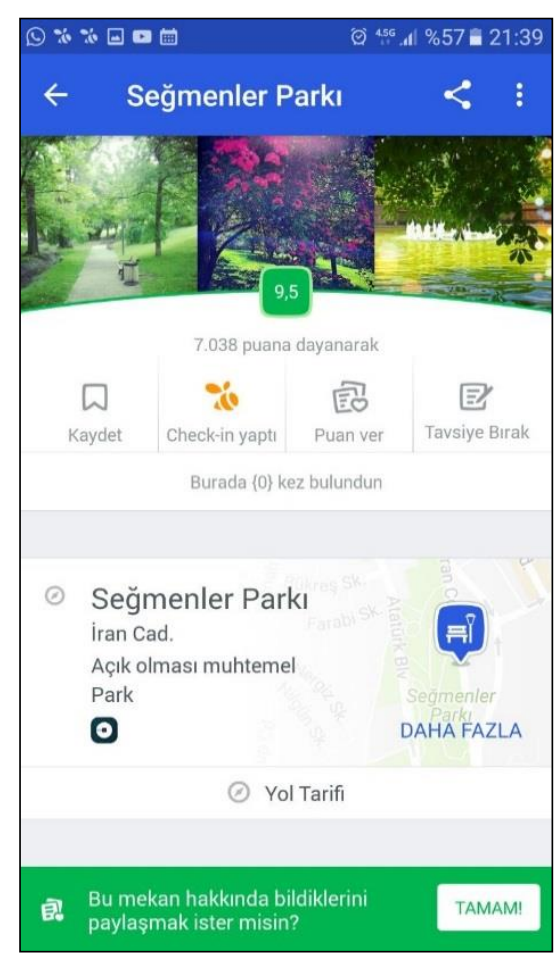

Şekil 7. Seğmenler parkının 7.038 puana dayanarak 10 üzerinden 9.5 puan alması (Foursquare mobil uygulaması-Aralık 2016).

\subsubsection{Fiziki mekânın tasarlanmasındaki mekân-insan ilişkisi:}

Coğrafi sosyal ağlardan Foursquare ve Swarm uygulamalarının en dikkat çekici özelliği tamamen iş birlikçi bir yapıya sahip olmasıdır. Burada bahsedilen işbirlikçi yapı kullanıcılara konumlarını, fotoğraflarını ve yorumlarını paylaşma imkânının sunulmasıdır. Tüm bu iş birlikçi yaklaşım coğrafi sosyal ağ kullanıcılarının paylaştıkları fotoğrafları ve yorumları ile mekânın iç-dış tasarımını, müşterilerce yorumlanan kullanım olanaklarını ortaya koymaktadır (Şekil 8). Ayrıca gün içerisinde mekânda yapılan yer bildirimleri ışığında mekânın müşteri yoğunluğuna da erişilebilmektedir. Gün içerisindeki müşteri yoğunluğu mekânın konumuna göre hafta içi ve hafta sonu farklılık göstermektedir. Örneğin Ankara kentinde Tepe Prime Avenue içerisinde bulunan Arabica Coffee House hafta içi 12:00 ile 14:00 arası en popüler saatte olması, iş merkezlerine yakınlığından dolayı, iş merkezlerinde çalışanların öğle aralarında mekânı tercih etmeleri ve bu saatlerdeki kullanımın buna bağlı olarak artmasını göstermektedir (Şekil 9). Hafta sonu ise aynı mekânda en popüler saatin 20:00 ile 00:00 olması kullanıcı profilinin değiştiğini göstermekte olup hafta içi ve hafta sonu kullanımının mesai saatlerine bağlı olarak farklı olduğunu işaret etmektedir. Mekânda yapılan yer bildirimleri sayesinde ulaşılan mekânın kullanım yoğunluğu hangi saatlerde mekânın revaçta olduğunu hem işletmeciler hem de müşteriler açısından mekânın fiziki yeterliliğini ortaya koymaktadır. Kent plancıları açısından da mekân yoğunluğu mekânın hangi saatlerde en çok kullanıldığını göstermekte olup mekânı tasarlarken ihtiyaçların belirlemesinde sayısal bir veri sunmaktadır. 


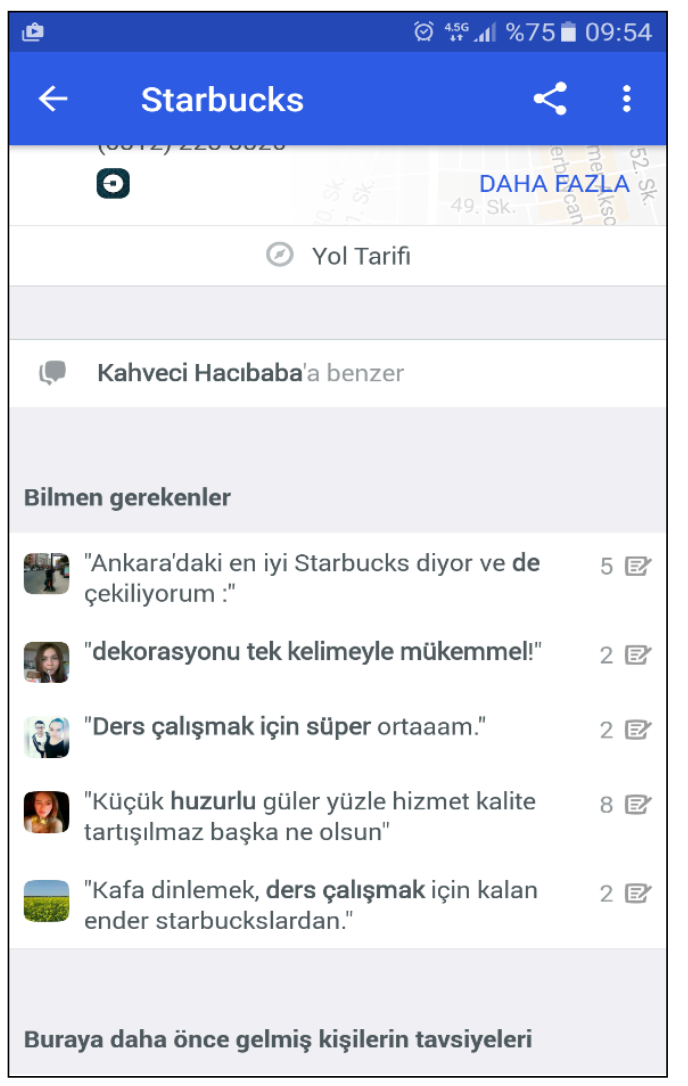

Şekil 8. Foursquare uygulamasının kullanıcı yorumlarına göre mekânın incelenmesi (Foursquare mobil uygulaması-Aralık 2016).

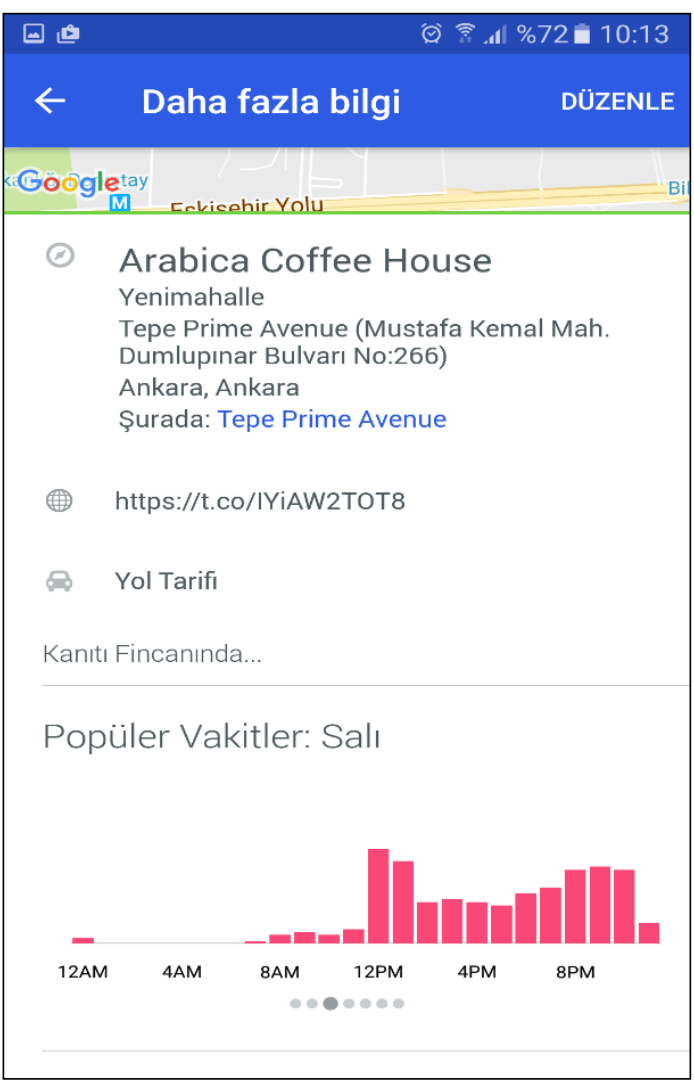

Şekil 9. Arabica Coffee House hafta içi (salı) kullanım saatleri Kaynakça: (Foursquare mobil uygulaması-Aralık 2016).

\subsubsection{Erişebilirlik ve hareketliliğe girdisi}

Kent planlamasına yardımcı olabilecek ulaşım haritaları konum verileri ile yapılabilmektedir. Farklı şehirdeki, farklı mahallelerin, farklı insanların sosyal medya üzerinden yaptığı yer bildirimleri hareketlilik haritalarına girdi oluşturmaktadır. Erişebilirlik ve hareketlilik kent plancılarına insanların mekânlarda nasıl hareket ettiği konusunda yardımcı olur (Ercoşkun, 2015).

Coğrafi sosyal medya verisi fiziksel alanların analiz edilmesini ve insan davranışlarından yola çıkarak o alanların tasarımlarının nasıl etkilendiğini göstermektedir. Analiz edilen alanlarda insanların kentte nerelerde dolaştığını, nereleri ziyaret ettiğini, bulunduğu alışveriş merkezlerini, yoğun trafik alanlarını, sessiz yaya yollarını, gece hayatı mekânlarını sunar. Bu mekânlar üzerinden sosyal medya verilerini inceleyerek kentin planı hakkında bilgiye sahip olunur. Örneğin, insanlar kahve içmek için ilgili bir yere gitmek istediklerinde kahve mekânları için nerelere gidilir sorusunu yönettiklerinde bu mekânlar listelenir (Tasse ve Hong, 2014). Örneğe göre gidilecek kahve mekânı seçildikten sonra Foursquare uygulaması üzerinden Google, Yandex gibi haritalardan navigasyon ile yol tarifi alma imkânı, gerçek zamanlı olup kişinin konumuna göre yeni rotalar belirleyip yaya, araç-araba, toplu taşıma gibi ulaşım türlerinde yol tarifi verilmektedir. Ayrıca durak ve terminal noktası gibi ayrıntılı bilgileri de içermektedir. Bu ulaşım bilgileri ile beraber aynı zamanda kişinin seçtiği ulaşım türüne bağlı olarak gitmek istediği kahve dükkânına gerçek zamanlı trafik raporu değerlendirilerek varacağı sürede otomatik hesaplanmaktadır (Şekil 10). 


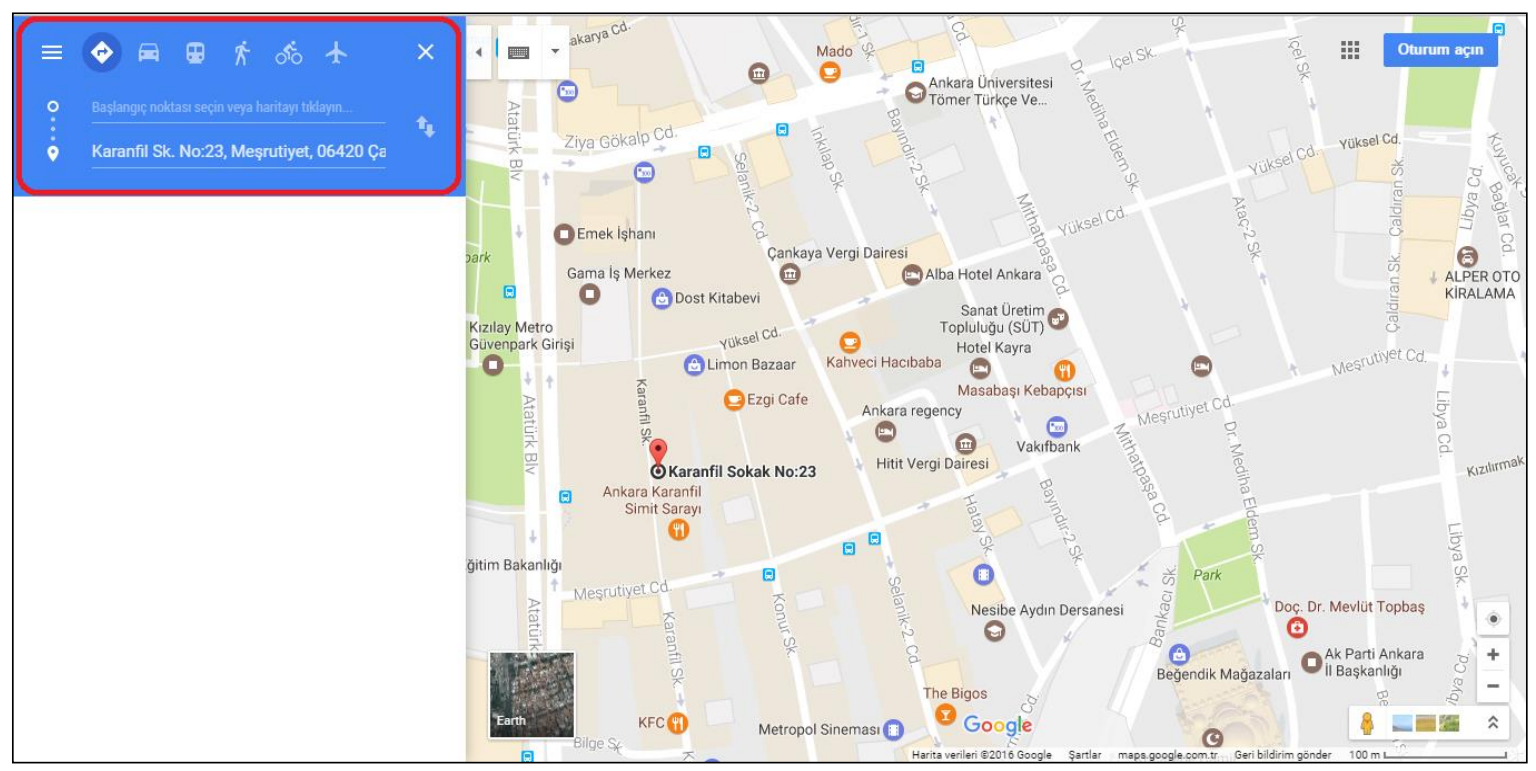

Şekil 10. Foursquare uygulaması ile bağlantılı haritalardan navigasyonla yol tarifi alma imkânı (Foursquare web sitesi, https://www.google.com/maps)

Planlanacak bölgenin veya incelenecek alanın Foursquare ve Swarm uygulamalarını kullanarak ulaşım türleri, durak ve terminaller, trafik yoğunluğu, kişi yoğunluğu, ulaşım imkânı sunan yollar gibi pek çok ulaşım bilgisi haritalarına girdi oluşturacak verileri sunmaktadır.

\subsubsection{Yer bildirimlerinin sosyo-ekonomik boyutu}

Kentler coğrafi konumlarının verdiği rekabetçi durumlarına ve hızlı ekonomik dinamiklerine göre gelişir. Kentlerde ekonomik büyüme özel coğrafi alanlar, yaratıcı insanlar ve yenilikçi girişimlere bağlıdır. Sosyal ağların bağımlılığının kentsel yoğunluğa göre incelenmesi yer paylaşımlarının Foursquare uygulaması kullanımına, kent merkezindeki sosyo-ekonomik farklılığa bağlıdır. Geçmişte kentler sosyo-ekonomik dinamiklerle gelişmiştir. Yenilikçilik, yaratıcı yaşam tarzları ve girişimcilik kentleri oluşturmuştur. İşletmecilerin ekonomik performansı, firmaların yeteneklerine ve çevre kaynaklarına bağlıdır. Firmaların büyümesi, kaynak yeterliliği veya kaynakları harekete geçirme durumuna bağlıdır. Son yıllarda, kaynak temelli büyüme fiziksel insan kaynakları ve sosyo-ekonomik kaynaklar açısından incelenmektedir. Sosyal yaşam kent yaşamının intiyacıdır. Foursquare-Swarm uygulamaları yer paylaşımı kentlerin ekonomik etkileşimini tahmin eder (Arribas-Bel, Kourtit ve Nijkamp, 2013). Mekân kullanıcıları mekânı Foursquare-Swarm uygulamalarının sunduğu çeşitli filtreleme yöntemlerinden mekânların ürün fiyatları ile maddi açıdan değerlendirebileceği gibi (ortalama sonucu çıkan) ürün fiyatlarını diğer filtrelemelerle birlikte de değerlendirebilip kullanabilirler.

Toplumsal hayatta sosyo-ekonomik statü grupları dinamik bir yapıdadır. Sosyo-ekonomik statü haritalanması devlet için oldukça önemli bir bölüm olup kaynakları geliştirmede önemli bir rol oynar. Örneğin İngiltere'de devlet çoklu ihtiyaçlar verisini kullanarak (IMD) yoksulluk probleminin en çok nerelerde olduğunu ölçmede kullanır. Bu yöntemi kullanarak sorunları çözmeye çalışır. IMD alt yapısı ve diğer istatistik bilgileri IMD'nin temeli araştırma ve devletin farklı alandaki istatistik bilgilerinden oluşmaktadır. Fakat gelişmiş ülkelerde bile araştırma ve istatistik bilgileri toplamak zorlu ve pahalıdır. Özellikle gelişmekte olan ülkelerde yoksulluk haritası kullanılırken veriler zamanı güncel veriler değildir. Güncel verileri toplamak, sisteme oturtmak ve analizi çalışır hale getirmek kolay bir süreç değildir. Ancak geleneksel yöntemlere göre bu analizin yapılması daha kolaydır. Bu analizin yapılmasındaki en önemli husus, verilerin ne kadar güncel olduğudur. Geleneksel yöntemlerle yapılan analizlerde sosyo-ekonomik yoksulluğu haritalandırırken daha büyük alanlara, daha az detaylı bilgiler verirken; sosyal medyanın sağladığı veriler ile hem daha hızlı hem de daha kolay veriler elde ederek sosyo-ekonomik haritaların analizleri daha hassas ve doğru olmaktadır (Tasse ve Hong, 2014). 
Bir başka girdi olarak kentteki kirlilik, şiddet, insanların uyumu gibi sosyo-ekonomik statüleri takip etmek zordur. Sosyo-ekonomik statü içerisinde yaşam kalitesinin de haritalandırması yapılabilir. Yaşam kalitesinin bazı yönleri konum verileri kullanılarak modellenebilir (Tasse ve Hong, 2014).

\section{Ankara'da En Çok Yer Bildirimi Yapılan 10 Kahve Mekânının Araştırması ve Bulguları}

Ankara Türkiye'nin başkenti olup Cumhuriyetin kuruluşuna tanıklık etmiştir. Tarihsel açıdan kent çok eskilere dayanmakta olup kültürel farklılıklar bulunmaktadır. Türkiye'nin 2. büyük şehri olan Ankara, İstanbul'dan sonraki en yoğun nüfusa sahip kenttir. Geniş bir alana yayılmakta olup politik, sosyal, ekonomik fonksiyonlar bakımından kentsel alanda yoğun bir şekilde kümelenmiştir. Cumhuriyetin başlangıcında imar planları yapılarak planlı yerleşim sağlanmıştır. 1940'lardan sonra kent çok büyük bir değişime girmiş ve nüfus inanılmaz boyutta artmıştır. Yükseköğretim kurumlarının fazla olması kentte kültürel gelişme sağlanmasına sebep olmuştur. Kent içerisinde yaşayan memurlar, öğrenciler şehrin nüfusunda önemli ölçüde rol oynar. Ankara'da kent merkezi Ulus-Kızılay-Tunalı hattıdır. Ana caddeleri, alışveriş merkezleri, oteller, tiyatrolar, yüksek katlı binalar dikkati çekmektedir. Kamusal mekânlar, kentin gelişme yönü olan güneybatı koridorunda bulunmaktadır. Opera, bale, tiyatrolar, konser salonları kent merkezinde hizmet vermektedir.

Ankara kentinde kahve mekânlarının örnek olarak alınmasıyla belirli bir zaman aralığı içerisinde Swarm uygulaması kullanımına bağlı yer bildirimleri Foursquare uygulamasının 4sweep uygulaması ile erişilmektedir (23.11.2016 10:55) (https://4sweep.com). Erişim sonucunda Ankara kentinde 2016 yılında en çok yer bildirimi yapılan kahve mekânları sırası ile:

1- Kahveci Hacıbaba (Kocatepe Mah. Selanik Cad. No:39/B Kızılay/Çankaya) (559.595 yer bildirimi)

2- Kahveci Hacıbaba (Muhsin Yazıcıoğlu Cad. No:30/D-E Çukurambar/Ankara) (289.573 yer bildirimi)

3- Starbucks (Yukarı Bahçelievler Mah. Aşkabat Cad. No:38/A Çankaya/Ankara) (282.889 yer bildirimi)

4- Kahveci Hacıbaba (Topçu Mahallesi 1464.Cad. (Elvankent Caddesi) No:59) (274.614 yer bildirimi)

5- Starbucks (Bahçelievler Mahallesi 54.Sokak No:4/A Çankaya/Ankara) (258.948 yer bildirimi)

6- Starbucks (Kızılay Avm Atatürk Bulvarı No:96 Çankaya/Ankara) (192.142 yer bildirimi)

7- Kahveci Hacıbaba (Azerbaycan Cad. No:45 Bahçelievler/Ankara) (184.925 yer bildirimi)

8- Kahveci Paşazade (Karanfil Sokak No: 22/A Kızılay/Ankara) (169.415 yer bildirimi)

9- Starbucks (Meşrutiyet Mah. Karanfil Sokak Kızılay/Çankaya) (164.922 yer bildirimi)

10- Starbucks (Turan Güneş Bulvarı Sancak Mah. No:19 Çankaya/Ankara) (157.914 yer bildirimi) olmaktadır (Şekil 11). 


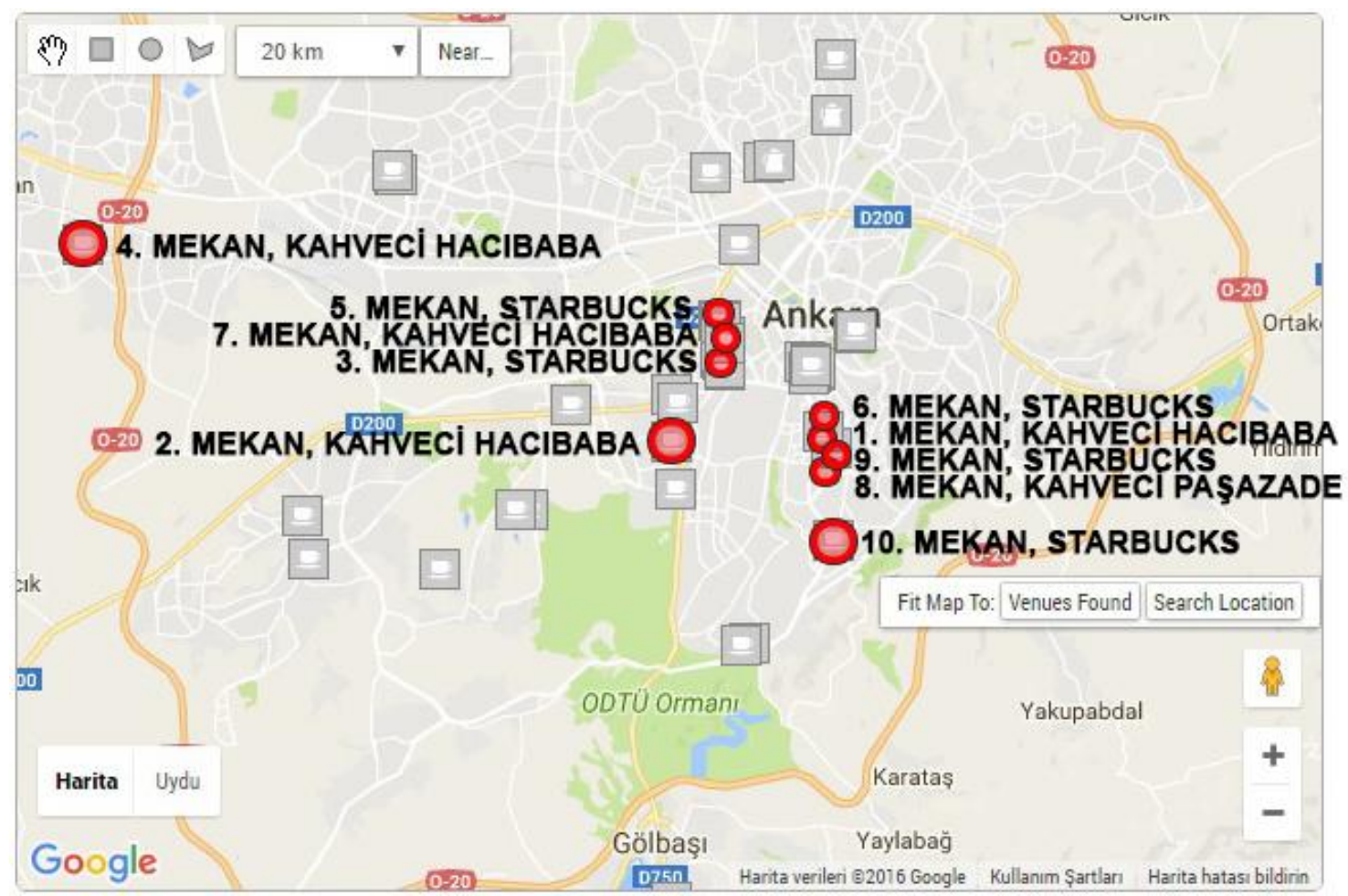

Şekil 11. Ankara kentinde en çok yer bildirimi yapılan, ilk 10'da bulunan kahve mekânları (URL-6).

Kahve mekânlarındaki yer bildirimlerin dağııımı mekânsal analiz edildiğinde, merkezi yoğun yerleşim alanlarında daha çok yer bildirimi yapıldığı sonucu görülmektedir. illk 10 kahve mekânı içerisinde Foursquare-Swarm uygulamaları üzerinden yer bildirimi yapılan yerlere bakıldığında 4 mekânın Kızılay'da bulunması Kızılay'ı 1. odak yapmaktadır. Bahçelievler'de ise ilk 10'a giren 3 kahve mekânının bulunması Bahçelievler'i 2. odak yapmaktadır. Kahve mekânlarında yer bildirimleri üzerinden rastgele-belirli sayıda seçilmiş kullanıcılar ankete tabi tutulmuştur. Araştırmada en çok yer bildirimi yapılan kahve mekânlarındaki kullanıcı profilleri, kullanıcı davranışları, mekânı seçme nedenleri, Foursquare Swarm uygulamaları kullanımına yönelik sorular ortaya konulmaktadır.

\subsection{Kahve Mekânlarındaki Kullanıcılarla Yapılan Anket Çalışması}

Swarm uygulaması üzerinden en çok yer bildirimi yapılan ilk 10'a giren kahve mekânlarının her birinde, yer bildirimi yapan kullanıcılar ankete tabi tutulmuştur (03.12.2016-04.12.2016). Her kahve mekânında 10'ar adet anket yapılmak üzere toplamda 100 adet anket yapılmıştır. 1 . soru ve 2. soru mekânın adı ve adresine yöneliktir. 3. soru ise (3.1., 3.2., 3.3., 3.4.) katılımcıya yöneliktir. 4. sorudan 18. soruya kadar katılımcının mekân ile ilişkisine yönelik, 19. sorudan 24. soruya kadarda katılımcının Foursquare-Swarm uygulamaları kullanımına ilişkin sorular sorulmuştur. Anket çalışması 43 erkek 57 kadın Swarm uygulaması kullanıcısına uygulanmıştır.

Katılımcıların en fazla oranını öğrenci grubu oluşturmaktadır ve diğer gruplar içerisinde öğrenci grubu $\% 56^{\prime}$ ।ık pay almaktadır. Katılımcıların \%56'ık kesimini öğrencilerin oluşturması, öğrencilerin mesai saatlerinin olmamasından kaynaklı gün içerisinde kahve mekânlarına belirli bir saat aralığında gitmediklerini gösterirken, aynı zamanda kahve mekânına günün herhangi bir saat diliminde gidebileceklerini de göstermektedir. Öğrenci katılımcılar kahve mekânlarını öncelikli olarak ders çalışabilmek, arkadaşlarıyla hoş zaman geçirebilmek ve kahve içmek amacıyla kullanmaktadır. \%56'ık kesimin öğrenci olması aynı zamanda Foursquare-Swarm uygulamalarını kullanan kişilerin genç olduğunu da göstermektedir.

Anket katılımcılarının \%55'ini 20 ile 24 yaş arasındaki kişiler oluşturmaktadır (Çizelge 1). Ortalama yaş değeri ise $25^{\prime}$ dir. Kahve mekânlarında müşterilerin birçoğu öğrenci olmakla birlikte, öğrencilerin de 20 ile 24 yaşları arasında yoğunlaştığını göstermektedir. 
Çizelge 1. Katılımcıların yaş dağılımı

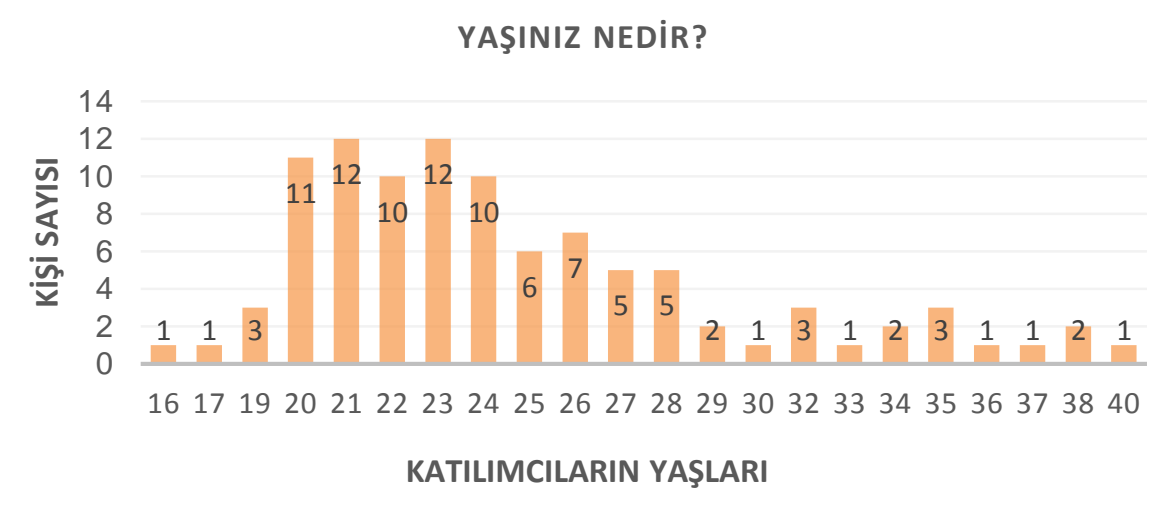

Anket katılımcıların \%90'ı bekâr, \%10'u evlidir. Katılımcıların evlerine yakınlığı katılımcıların \%71'i için önemli, \%29'u için önemli değildir (Çizelge 2).

Çizelge 2. Kahve mekânlarının katııımcıların evlerine yakını̆ğının katııımıılar için önemi

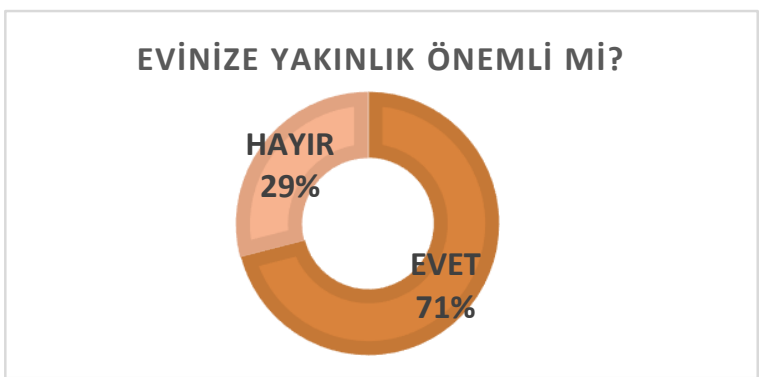

Katılımcıların iş yerlerine yakınlığı katılımcıların \%30'u için önemli, \%16'sı içinde önemli değildir (Çizelge 3) ve \%54'lük kesim bu soruya her hangi bir yerde çalışmadıkları için cevap vermemişlerdir.

Çizelge 3. Kahve mekânlarının katılımcıların iş yerlerine yakınlı̆ının katılımcılar için önemi

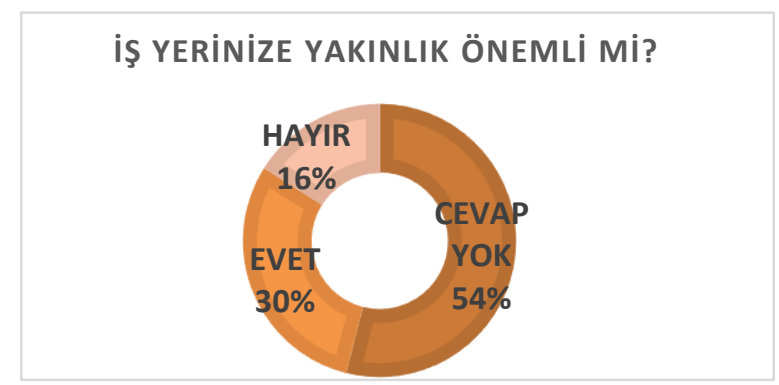

AVM'lere yakınlık katılımcıların \%67'si için önemli, \%32'si içinde önemli değildir (Çizelge 4). AVM yakınında bulunan kahve mekânlarındaki katılımcılar sadece kahve içmek için gelmemekte olup günün belirli saatlerinde kahve içmeyi, geri kalan boş vakitlerinde ise alışveriş yapmayı tercih etmektedirler. Bunun sonucunda genel olarak AVM yakınlarındaki kahve mekânları işlek kahve mekânlarıdır.

Çizelge 4. Kahve mekânlarının AVM'lere yakınlığının katılımcılar için önemi

AVM' YE YAKINLIK ÖNEMLI MI?

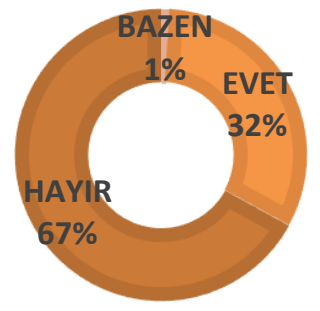


Kent merkezine yakınlık (Ulus-Kızılay-Tunalı) katılımcıların \%60'ı için önemli, \%40'ı içinde önemli değildir (Çizelge 5). Kahve mekânlarının kent merkezine yakınlığının tercihi ulaşım imkânları, diğer kentsel kullanım olanaklarına yakınlık gibi nedenler yönündedir. Kent merkezine yakın olan kahve mekânları daha işlektir.

Çizelge 5. Kahve mekânlarının kent merkezine yakınlığııın katılımcılar için önemi

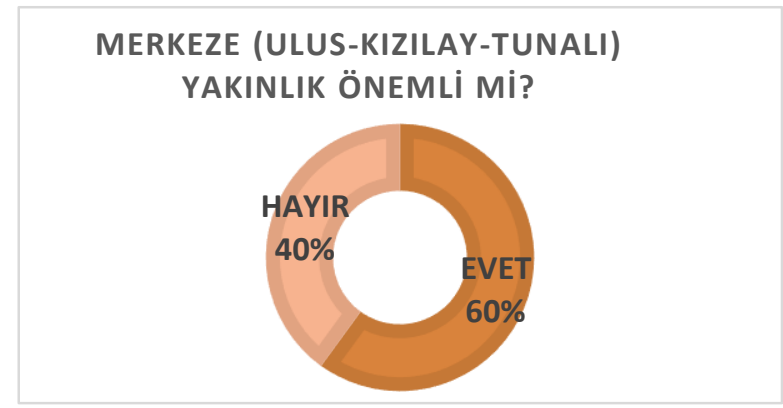

Ana alışveriş caddesine yakınlık katılımcıların \%82'i için önemli, \%17'si içinde önemli olmamaktadır (Çizelge 6). Ana alışveriş caddesinde kentsel kullanımların çeşitliliğinin fazla olmasından dolayı katılımcının pek çok ihtiyacını karşılayabileceği yönündedir. Ana alışveriş caddesine yakın kahve mekânları daha işlek mekânlardır.

Çizelge 6. Kahve mekânlarının ana alışveriş caddesine yakınlığının katııımcılar için önemi

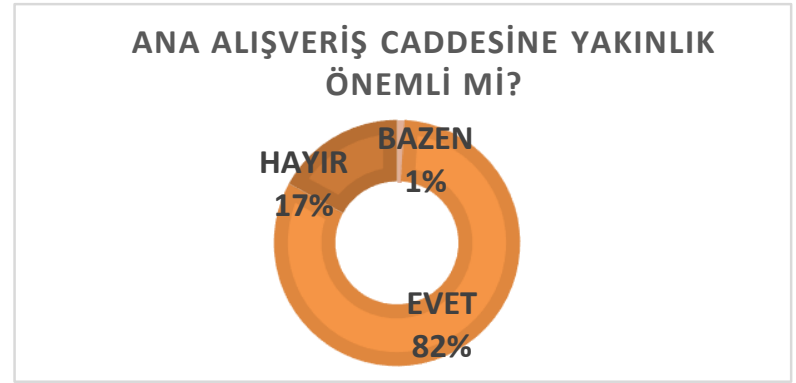

Katılımcıların \%74'ü kahve mekânlarını rutin olarak kullanmakta, \%26'sı ise rutin olarak kullanmamaktadır (Çizelge 7). Katılımcıların \%74'lük kesimin rutin olarak gelmesi kahve mekânlarının oldukça işlek olduğunu ve hiçbir zaman kahve mekânlarının müşterisiz kalmadığı bilgisine ulaşılmaktadır.

Çizelge 7. Kahve mekânlarının rutin kullanımı

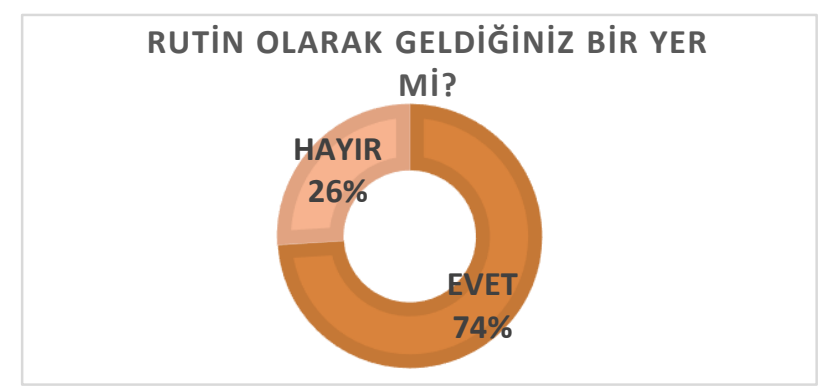

Katılımcıların \%54'ü mekâna ayda birkaç kez, \%33'ü haftada birkaç kez, \%8'i yılda birkaç kez ve \%5'ide her gün gelmektedir (Çizelge 8). 
Çizelge 8. Kahve mekânlarının kullanım sıklığı

MEKANA NE SIKLIKLA GELIYORSUNUZ?

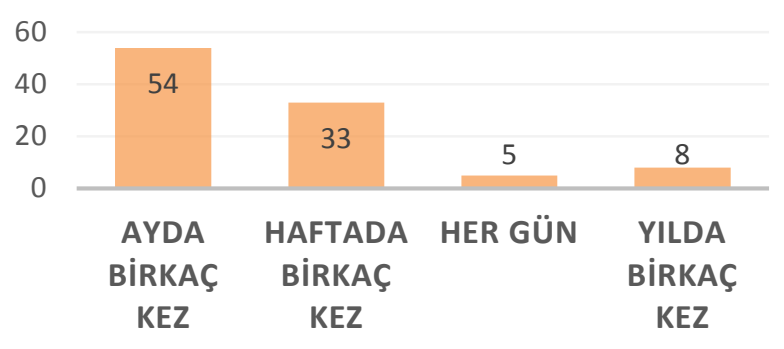

Mekânın iç tasarımı katılımcıların \%92'sini etkilemekte, \%7'sini etkilememekte ve \%1'inide bazen etkilemektedir (Çizelge 9). Görsellik, mekân ambiyansı kahve mekânları müşterileri için önemli bir faktördür. Katılımcılar ile anket yapılırken gelen yorumlarda katılımcıların güzel bir mekânda zaman geçirmek istediği, bu isteğinde mekânın iç tasarımı ile olacağı ortak görüşü gelmiştir.

Çizelge 9. Kahve mekânlarının iç mekan tasarımlarının katılımcıyı etkilemesi

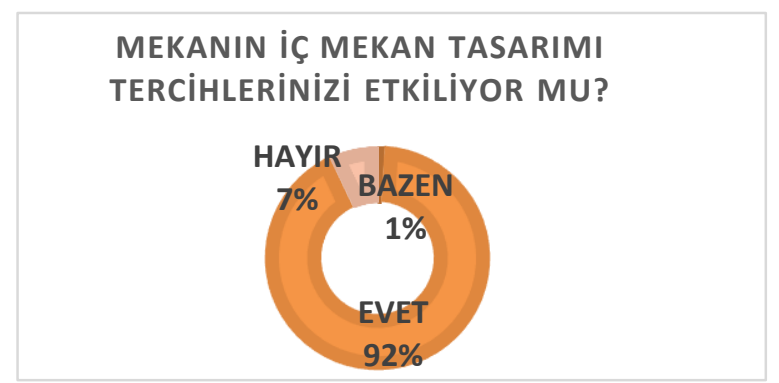

Mekanda bulunan açık alan kullanımı katılımcıların \%95'i etkilemekte, \%4'ünü etkilememekte ve \%1'inide bazen etkilemektedir (Çizelge 10). Mevsimsel olarak katılımcının açık havada bulunma isteği ve buna bağlı olarak açık havada oturma isteğinin en önemli etmeni tütün ürünleri kullanımına dayanmaktadır.

Çizelge 10. Kahve mekanlarının açık alan kullanımının katılımcıyı etkilemesi

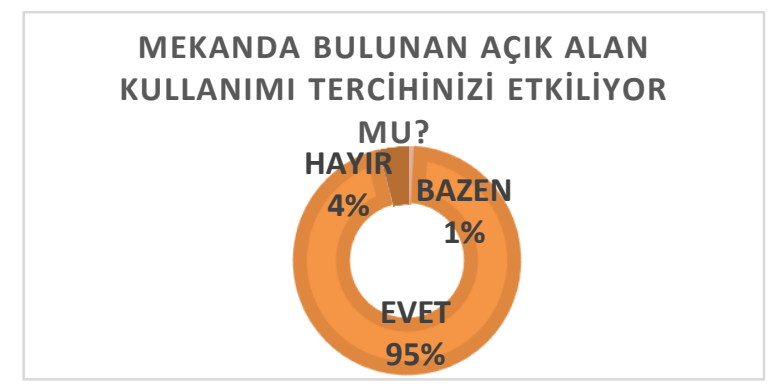

Mekânda bulunan sigara içme terası katılımcıların \%64'ünü etkilememekte, \%35'ini etkilemekte ve $\% 1$ 'ni de bazen etkilemektedir (Çizelge 11).

Çizelge 11. Kahve mekânlarında bulunan sigara içme terasının katılımcıyı etkilemesi

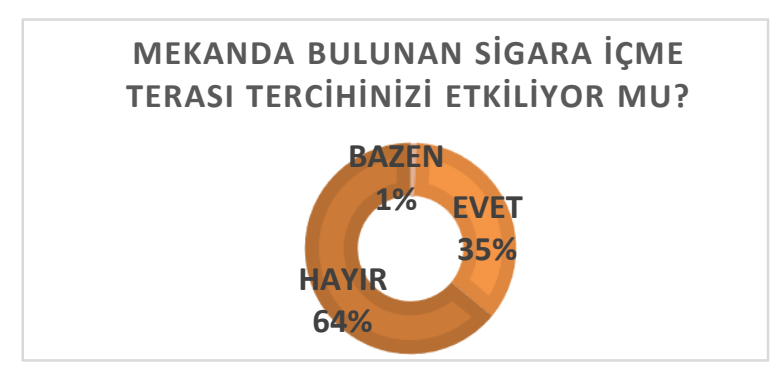


Mekânlardaki çocuk alanı kullanımı katılımcıların \%94'ünü etkilememekte, \%4'ünü etkilemekte ve \%2'sinide bazen etkilemektedir (Çizelge 12). Katılımcıların \%94'lük kesiminin küçük yaşta çocuklarının olmadığını veya katılımcının çocuğunun olmadığını göstermektedir.

Çizelge 12. Kahve mekânlarında bulunan çocuk oyun alanı kullanımının katııımıyı etkilemesi

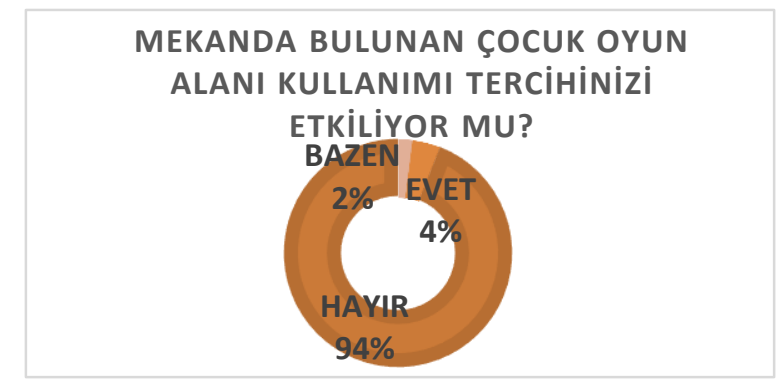

Kahve mekânlarının otopark imkânı sunması katılımcıların \%49'unu etkilemekte, \%39'unu etkilememekte ve \%12'inide bazen etkilemektedir (Çizelge 13). illk 10'da bulunan kahve mekânlarının çoğunun otopark imkânı yoktur. Fakat arabalı kullanıcıları içeren \%49'luk kesim kahve mekânlarına gene de gitmektedir. Mevcut kahve mekânlarına veya yeni açılacak kahve mekânlarına otopark imkânı sunulması takdirinde, katılımcının bu mekânları tercih etmesinin önemi de artacaktır.

Çizelge 13. Kahve mekânlarının otopark imkânı sunmasının katılımcıyı etkilemesi

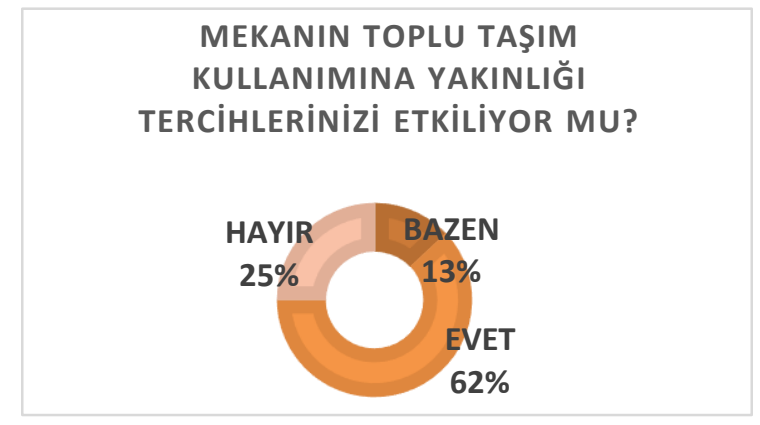

Kahve mekânlarının toplu taşıma duraklarına yakınlığı katılımcıların \%62'sini etkilemekte, \%25'ini etkilememekte ve \%13'ünüde bazen etkilemektedir (Çizelge 14). Illk 10'da bulunan kahve mekânlarından 5 tanesinin Kızılay'da, 3 tanesinin de Bahçelievler'de konumlanması bu mekânların toplu taşım kullanımı açısından Ankara kentinin en gelişsmiş yerleri olmasını ve bu sebepten dolayı da müşterilerin kahve mekânlarına ulaşımda toplu taşımayı kolaylıkla tercih ettiğini, edebileceğini göstermektedir.

Çizelge. 14. Kahve mekânlarının toplu taşım kullanımına yakınlı̆ıııı katılımcıyı etkilemesi

\begin{tabular}{|c|}
\hline MEKANIN TOPLU TAŞIM \\
KULLANIMINA YAKINLIĞI \\
TERCIHLERINIZI ETKILIYOR MU? \\
HAYIR \\
$25 \%$ \\
BAZEN \\
$13 \%$ \\
EVET \\
$62 \%$
\end{tabular}

Kahve mekânlarının sunduğu ürün çeşitliliği katılımcıların \%95'ini etkilemekte, \%3'ünü bazen etkilemekte ve \%2'sinide etkilememektedir (Çizelge 15). Ürün çeşitliliği kahve mekânlarının tercihlerine bağlı olmakla birlikte, müşterilerinde ürün çeşitliliğini sevdiğini ortaya çıkarmaktadır. Bu 
çeşitlilik belirli bir kahve dükkânının tercihlerini belirli bir noktada yoğunlaşmasını sağlayarak markalaştırabilir veya mevcut kahve dükkânının yanına açılacak yeni bir kahve dükkânının çeşitliliğini de etkileyebilir.

Çizelge 15. Kahve mekânlarında sunulan ürün çeşitliliğinin katııımcıyı etkilemesi

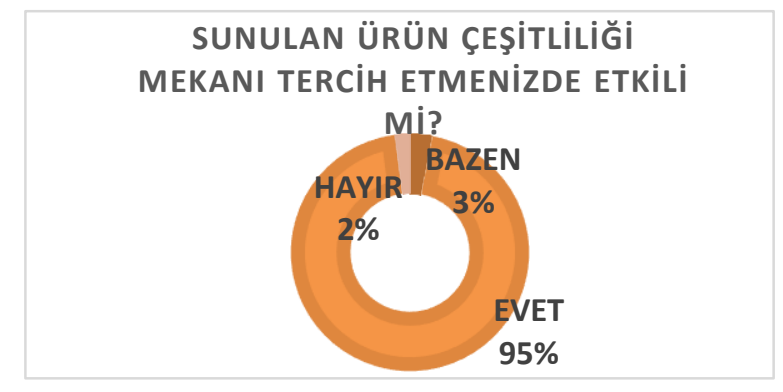

Kahve mekânlarının belirlediği ürün fiyatları katılımcıların \%83'ünü etkilemekte, \%15'inide etkilememektedir (Çizelge 16). Katılımcıların \%56'sının öğrenci olmasına bağlı olarak mekânların ürün fiyatları önemli rol oynamaktadır.

Çizelge 16. Kahve mekânlarında ürün fiyatlarının katılımcıyı etkilemesi

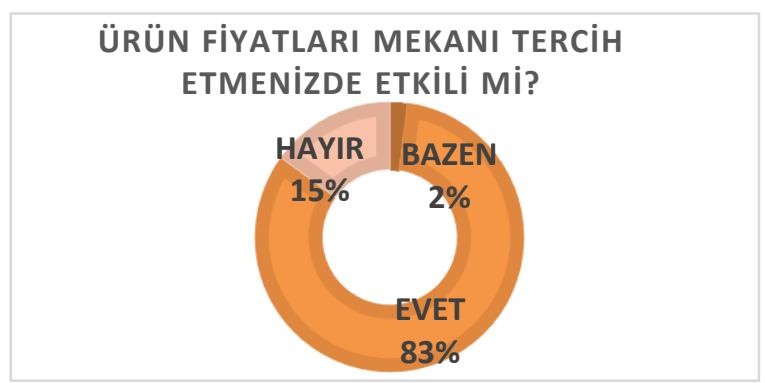

Foursquare uygulamasını katılımcıların $\% 46$ 'sı ayda birkaç kez, $\% 29$ 'u haftada birkaç kez, \%14'ü her gün ve \%11'ide yılda birkaç kez kullanmaktadır (Çizelge 17). Forsquare uygulaması kullanıcıları tarafından sosyal medya üzerinden mekânların özelliklerine bakılmasında, fotoğraf ve bilgi paylaşımının yoğun olmasından dolayı Foursquare uygulaması kullanımı genellikle yeni bir mekân keşfetmek için girilmektedir.

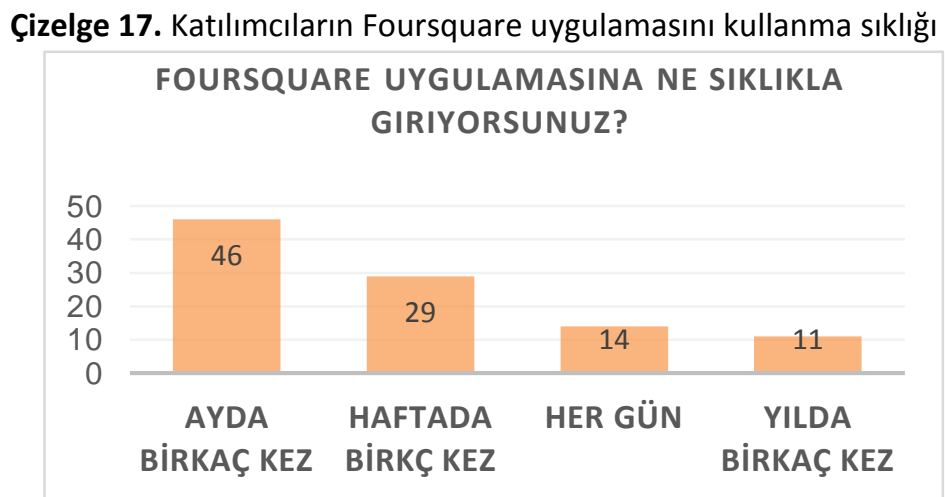

Foursquare-Swarm uygulaması üzerinden katılımcıların $\% 45$ 'i her gün, $\% 26$ 'sı haftada birkaç kez, $\% 25^{\prime} \mathrm{i}$ ayda birkaç kez ve \%4'üde yılda birkaç kez yer bildirimi yapmaktadır (Çizelge 18). Çıkan sonuç teorik kısımda anlatılan araştırma yöntemlerinin (mekânın türü analizi ve erişebilirlik, hareketliliğe girdi oluşturması) güncel ve güvenilir olduğunu kanıtlar düzeydedir. 
Çizelge 18. Katılımcıların Foursquare-Swarm uygulamasında yer bildirimi yapma sıklığı

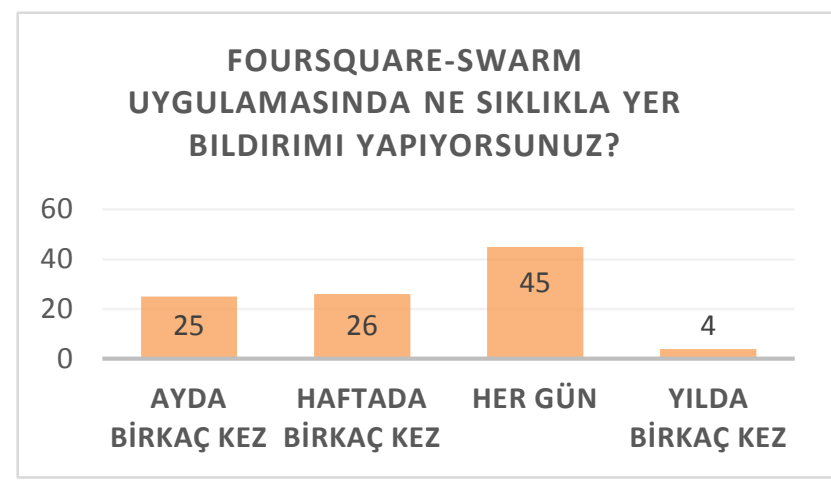

Foursquare uygulaması üzerinden mekân tavsiyelerine katılımcıların \%59'u bakmakta, \%26'sı bazen bakmakta ve \%15'ide bakmamaktadır (Çizelge 19). Foursquare uygulaması kullanıcıları "Foursquare uygulamasına ne sıklıkla giriyorsunuz?" sorusuna bağlantılı olarak yeni mekânlar keşfederken, daha önceki müşterilerin deneyimleri doğrultusunda yaptığı yorumlar, yeni ve potansiyel müşteriler için önemli rol oynamaktadır. Anket sorusu sonucunda katılımcıların büyük bir çoğunluğunun (\%59) yorumları dikkate aldığı sonucu çıkmaktadır.

Çizelge 19. Katılımcıların Foursquare uygulamasında tavsiyeleri kullanması

\begin{tabular}{|c|}
\hline MEKANA GITMEDEN ÖNCE \\
FOURSQUARE'DAKI TAVSIYELERE \\
BAKIYOR MUSUNUZ? \\
HAYIR \\
$15 \%$ \\
BAZEN \\
EVET \\
$59 \%$ \\
\hline
\end{tabular}

Mekânda yapılan yer bildirimi sayısı katılımcıların \%51'ini etkilemekte, \%41'ini etkilememekte ve \%8'inide bazen etkilemektedir (Çizelge 20). "Mekâna gitmeden önce Foursquare'daki tavsiyelere bakıyor musunuz?" sorusunda da olduğu gibi mekânda bulunan önceki kullanıcıların yaptığı yer bildirimlerinin sayılarına bakılmakta ve bu yer bildirimi sayılarının azlığı-çokluğu "Foursquare uygulamasına ne sıklıkla giriyorsunuz?", "Foursquare-Swarm uygulamasında ne sıklıkla yer bildirimi yapıyorsunuz?" sorularının da devamı olarak bir mekândaki yer bildirimi sayısı yeni ve potansiyel müşterileri etkilemektedir.

Çizelge 20. Katılımcıların Foursquare-Swarm uygulamasında yer bildirimlerini incelemesi

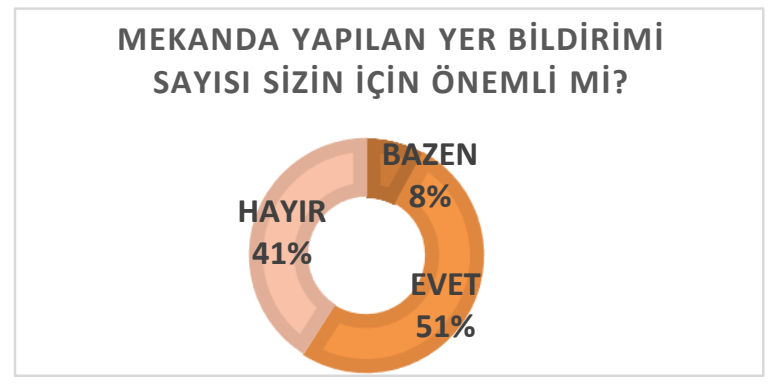


Swarm uygulamasını oyun amaçlı olarak katılımcıların \%42'si kullanmakta, \%30'u kullanmamakta ve \%28'i bazen kullanmaktadır. Katılımcıların \%56'lık kesiminin öğrenci olmasından dolayı FoursquareSwarm uygulamalarının sunduğu oyun amaçlı kullanım, katılımcıların arkadaşlarıyla rekabet edebilmesi amacıyla kullanılmaktadır.

Kahve mekanlarının sunduğu Foursquare-Swarm uygulamaları üzerinden indirim olanakları mekan tercihinde katılımcıların \%49'unu etkilemekte, \%32'sini bazen etkilemekte ve \%19'unuda etkilememektedir (Çizelge 21). Katılımcılar için mekânda sunulan indirimler önemli rol oynamaktadır. Müşteriler genellikle indirimi olan yerleri tercih etmektedir.

Çizelge. 21. Foursquare-Swarm uygulamasının sunduğu indirimlerin katılımcıların mekânı tercih etmesini etkilemesi

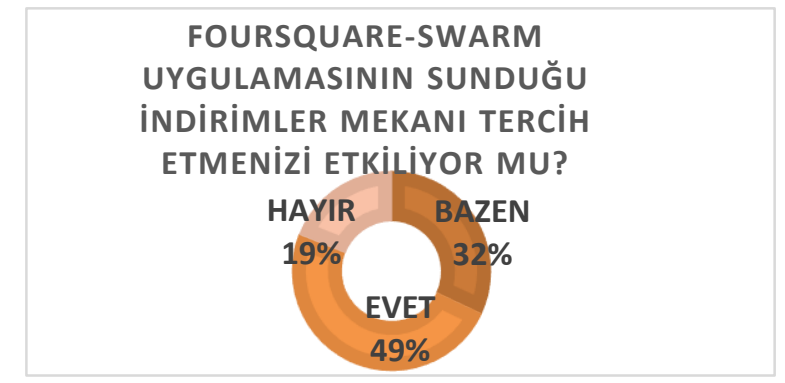

\subsection{Kahve Mekânlarındaki Mekân İşletmecileriyle Yapılan Anket Çalışması}

Foursquare-Swarm uygulamaları üzerinden kahve mekânları arasında yer bildirimi sayısı ve niteliği bakımından ilk 10 listesine giren kahve mekânlarına bakılmıştır. İlk 10'a giren kahve mekânları içerisinde Kahveci Hacıbaba'ya ait 4 şube, Starbucks'a ait 5 şube, Kahveci Paşazade'ye de ait yalnızca 1 şube bulunmaktadır. Mekân sahiplerine yapılan anket çalışması yalnızca Bahçelievler'de bulunan Kahveci Hacıbaba ve Starbucks şubelerine yapılmıştır. Diğer şubelere anket çalışmasının yapılmamasının sebebi kahve dükkânlarının ait olduğu markaların aynı standartları taşımalarıdır. Mekânların toplu taşıma duraklarına olan yakınlıkları, AVM'ye yakınlığın ve merkeze yakınlığın önemli görülmemesi, ana alışveriş caddesine yakınlığın ise önemli bulunması işletmecilere yapılan anketlerde kahve dükkânlarının firma olarak ortak özelliklerini ortaya koymaktadır. Açık alan kullanımları tüm işletmeciler tarafından önemli ve olumlu yönde etkisi olduğu düşünülse de, mekânların firma olarak birbirinden ayrışan özellikleri bulunmaktadır. Kahveci Hacıbaba dükkânları bahçe kullanımı üzerine kurulmuş bir mekân kurgusuna sahip iken Starbucks dükkânları daha çok iç mekân tasarımı üzerinde kurguya sahiptir. Bir başka markaların farklılaşma unsuru ise her iki mekânında müşteri profilinin öğrenciler olmasının yanı sıra Kahveci Hacıbaba mekânına 40-50 yaş grubunda müşterilerinde geliyor olmasıdır. Bu yaş grubu farkına bağlı olarak Kahveci Hacıbaba mekânına gelen müşteriler çocuk oyun alanına yönelik talep getirmekte olup, Kahveci Hacıbaba mekânlarında da buna yönelik çalışmalara başlanmıştır. Ayrıca seçilen Kahveci Hacıbaba mekânında otopark hizmeti sunulurken seçilen Starbucks kahve mekanında otopark hizmeti sunulmamaktadır.

\section{SONUÇ}

Kent planlama, kademeli ilerleyen planlar doğrultusunda işleyen bir mekanizmadır. Bu mekanizma birkaç kentin oluşturduğu ve çeşitli coğrafi-siyasi-ekonomik unsurlardan meydana gelen bölgelerden başlayarak kentlere, kentlerden mahallelere ve daha da küçük birimlere kadar inerek detaylanan ölçekler doğrultusunda ele alınır. Bir kent planlama sürecinde mekânlar yalnızca fiziksel olarak düşünülmez. Ekonomik, sosyal, siyasi, kültürel ve uluslararası bağlantılara kadar çıkabilen hem çok geniş bir çerçeve de bakılan hem de oldukça detaylı ve her türü alternatifin göze alınıp değerlendirildiği zor bir süreçtir. Kentler planlanırken her türlü boyutun dikkate alınmasında ki temel neden, insanlar ve insanlarla ilgili her türlü konunun kent planlamasına girdi sağlamasıdır. Kent planlamada söz konusu olan boyutların detaylı analizleri sonucu 10, 20, 25 yıl gibi hedeflenen süreler içerisinde gelişim konu alınır. Kentlerin oluşturduğu coğrafi-siyasi-ekonomik unsurlardan meydana 
gelen bölgeler ölçek detaylanarak şekillenir. Ülkelerin genel yapısını oluşturan bu zorlu süreç yalnızca kent plancılarının istekleri üzerine gerçekleşmez. Kent planlama katılımcı anlayışla gelişen demokratik bir yaklaşımdır. Günümüzde teknolojinin hızla ilerlemesi insanların hayatını hızlandırmış ve ulaşılması çok zor olarak düşünülen şeyler teknoloji ile yapıır hale gelmiştir. Teknoloji hayatımıza pek çok alanda katkı yaptığı gibi şehir planlamaya da katkı sağlamıştır. Teknolojinin kent planlamaya sağladığı katkılardan biride kentlilerin planlama süreçlerine katılımlarıdır. Bu çalışmada ulaşılmak istenen kentlilerin planlama sürecine olan katılımlarını arttıracak yollar üzerine yapılmıştır. Çalışmada temel alınan coğrafi konum tabanlı sosyal ağların (Foursquare-Swarm uygulamalarının) seçim nedeni anlık veriye ulaşılabilme, güncelliğini koruyabilmesi, zamansal süreçte görüntülenme, kullanıcının duygu ve düşüncelerine ulaşabilme ve sosyo-ekonomik çıkarımlarda bulunabilme imkânlarını sunmasıdır. Ayrıca Türkiye'nin Foursquare-Swarm kullanımında dünya birincisi olması veri güvenilirliği açısında oldukça önemli bir boyuttur.

Ankara ilinde coğrafi konum tabanlı sosyal ağlar kullanarak yapılan bu çalışmada amaç bahsedilen teorik çerçevenin pratikteki uygulamasının yapılarak kent planlama analizlerine alternatif yeni bir analiz türü eklemektir. Foursquare-Swarm uygulamaları doğrudan kent planına katılım için üretilmiş uygulamalar olmasa da bir plancının ihtiyaç duyabileceği pek çok veriye erişim imkânı sunmaktadır. Bu uygulamaların en güzel yanı ise geleneksel analiz yolları ile yapılan planlama analizleri uzun süren, emek isteyen ve maliyetli çalışmalar iken Foursquare-Swarm uygulamaları ile konu edilen modern planlama analiz teknikleri hızlı, iş gücü gerektirmeyip masrafsız olmasıdır.

Ankara ilinde yürütülen çalışmada en çok yer bildirimi yapılan kahve mekânlarındaki müşterilerin kullanıı profilleri, kullanıcı davranışları, mekânı seçme nedenleri, Foursquare Swarm kullanımına yönelik bulgular elde edilmiştir. Bu bulgular ışığında müşteriler bir mekâna gitmeden önce mekân hakkında Foursquare-Swarm uygulamalarından bilgi edinip tercihlerini yapmaktadırlar. Müşteri tercihleri Foursquare-Swarm uygulamalarını kullanan kişilerin mekânlar hakkındaki yorumlarınatavsiyelerine ve mekânlarda yapılan yer bildirim sayılarına bakarak gidebilecekleri mekânı belirlemektedir. Ankara kentindeki kahve mekânlarında yapılan yer bildirimi sayıları en fazla olan yerler kent merkezinde olması dikkat çekmiş ve bu doğrultu da yapılan yorum-tavsiyelerde müşterileri kent merkezine yöneltmiştir. Müşterilerin buralardaki kahve mekânlarını seçmesi kahve mekânlarını merkezileştirmiştir. Kullanıcılar kent çeperindeki kahve mekânlarına nazaran merkezdeki kahve mekânlarını tercih etmektedir. Müşteriler aynı zaman da mekânların açık alan kullanımı, otopark hizmeti, ürün fiyatı ve çeşitliliği gibi kriterleri de filtrelemektedir. Foursquare-Swarm uygulamaları kullanıcıları büyük oranda 20-24 yaşlarındaki üniversite öğrencilerinden oluşmaktadır. Buna bağlı olarak kahve mekânları yoğun ders çalışma yerleri olarak düşünülebilmektedir. Konut alanlarına yakın ticaret alanlarındaki kahve mekânları daha çok tercih edilmektedir. Ana alışveriş caddelerinde bulunan diğer ticari birimler gibi kahve dükkânlarının da ana alışveriş caddelerinde bulunması, kahve mekânı kullanıcılarını olumlu yönde etkilemektedir. En çok yer bildirimi yapılan kahve mekânlarının tercihinde diğer bir önemli unsurda kahve mekânların toplu taşım kullanımına yakın olmasıdır. Kullanıcılar merkezi alanları genellikle tercih etmektedir. Mekânın iç tasarımı, mekânda açık alan kullanımı ve sigara içme terası bulunması kullanıcıları büyük ölçüde etkilemekte olup mekânların iç tasarımları bu doğrultuda tasarlanmalıdır. Kahve mekânlarının rutin olarak kullanımı, yer bildiriminin düzenli yapılması elde edilen verileri güncel tutmaktadır.

Kent plancıları elde edilen bu mekân analizlerinden arazi kullanımı analizine gidebilmektedir. Foursquare-Swarm uygulamaları sayesinde kent plancıları merkezi iş alanlarının ticaret dokusunun fiziksel-sosyal-ekonomik boyutunu çıkarabilir; ticari birimlerin mekân türünü, grubunu, yoğunluğunu kat analizlerinde göstererek kapsamlı çalışmalara iş gücü ve maliyet gerektirmeden ulaşabilir. Aynı zamanda konut ve açık yeşil alan kullanımları gibi farklı arazi kullanımlarını ilişkilendirerek erişebilirlik, hareketlilik analizleri kent plancıları tarafından yapılabilir.

Kent planlamanın katılımcı demokratik ruhu ve planlama sürecindeki analiz aşaması için coğrafi sosyal ağlar önem taşımaktadır. Facebook gibi Sosyal ağlar platformları günümüzde Foursquare-Swarm uygulamalarında olduğu gibi coğrafi tabana geçiş yapmışlardır ve bu özelliği ilerletme yolunda adımlar atmaktalardır. Ayrıca Foursquare-Swarm uygulamalarının kullanıcı sayıları gün geçtikçe dünya 
çapında artış göstermesi bilakis Türkiye'nin bu konuda dünya lideri olması bu tarz coğrafi sosyal ağlara olan ilginin günümüzdeki önemini ve gelecekte artacak olan önemini ortaya koymaktadır. Ancak günümüz de her şeye rağmen Foursquare-Swarm uygulamaları bazı sorunlarla karşılaşmaktadır. Öncelikli olarak bu sorunlar Foursquare-Swarm uygulamalarını genelde genç ve orta yaş bireylerin kullanması, yaşlı bireylerin ise bu uygulamayı çeşitli sebeplerden dolayı henüz kullanmamasıdır. Bir başka sorun ise Foursquare-Swarm uygulamaları kullanımında, bazı kentlilerin yer bildirimi yapma imkânının olmamasıdır. Bu imkânsızlık teknoloji yetersizliği ve internet erişiminin sınırlı olmasından kaynaklanmaktadır. Yer bildiriminin fazla olabilmesi için kentlerde Wi-Fi ağlarına intiyaç vardır. Bilişim teknolojilerinin son yıllarda gelişimi ile yeni neslin oluşturduğu bireyler mobil cihaz ve bilgisayar çevrelerinde büyümelerinden dolayı bilişime yatkınlıkları ile Foursquare-Swarm uygulamaları üzerinde daha etkili olacaklardır. Gelecekte Foursquare-Swarm uygulamaları kendi bünyelerinde kentlere bu çalışma anlamında katkı sağlayacak geliştirmeler yapabilir ya da kent planlamasına yönelik Foursquare-Swarm uygulamaları örnek alınarak üretilen coğrafi sosyal ağlar ile doğrudan katkı sağlanabilir. Kent plancıları, kent tasarımcıları mobil teknolojilerin kullanımında fiziki mekânın rolünü anlamalıdır. Fiziki mekânda coğrafi sosyal ağlar önemli rol oynar.

\section{Kaynaklar}

Arribas-Bel, D., Kourtit, K. \& Nijkamp, P. (2013). Socio-cultural Diversity and Urban Buzz, TI, 110/VIII.

Arslan, A. (2014). Medyanın Birey, Kültür ve Toplum Üzerine Etkileri, Uluslar Arası İnsan Bilimleri Dergisi, İsmail Kurağ Karamanoğlu Mehmet Bey Üniversitesi, Kamu Yönetimi.

Baraniuk, C. (2013). Foursquare checck-ins tell stores where to set up shop,New Scientist, p.21.

Ercoşkun, O.Y. (2015). Exploring Geo-Social Networks For Urban Studies, SGEM 2015 International Multidisciplinary Scientific Conferences on Social SCIENCES and Arts.

Eren, V. ve Aydın, A. (2014). KMÜ Sosyal ve Ekonomik Araştırmalar Dergisi 16 Özel Sayı I, 2014:197,205.

Tasse, D. \& Hong, J.I (2014)., Using Social Media Data to Understand Cities, CHIMPS Lab, Paper 151.

URL-1. https://tr.wikipedia.org/wiki/Sosyal_medya\#Geleneksel_medyadan_farklar.C4.B1, 18.11.2016.

URL-2. http://foursquareturkiye.com

URL-3. https://tr.foursquare.com/infographics/500million-Aralık 2016

URL-4.https://tr.foursquare.com/v/kahveci-hac\%C4\%B1baba/4d18e83b6d103704b0b342bd, 12.12.2016 23:10.

URL-5.https://4sweep.com/explorer/explore\#II=39.930661,32.825958\&radius=25000\&s=venuesearch, 11.12.2016 16:30.

UR-6.https://4sweep.com/explorer/explore\#near=Ankara\&s=venuesearch\&cats=4bf58dd8d48988d1e0931735, 23.11.2016 11:25 